\title{
ADAM17: An Emerging Therapeutic Target for Lung Cancer
}

\author{
Mohamed I. Saad ${ }^{1,2}\left(\mathbb{O}\right.$, Stefan Rose-John ${ }^{3}(\mathbb{1})$ and Brendan J. Jenkins ${ }^{1,2, *}$ \\ 1 Centre for Innate Immunity and Infectious Diseases, Hudson Institute of Medical Research, \\ Clayton, Victoria 3168, Australia \\ 2 Department of Molecular and Translational Sciences, Faculty of Medicine, Nursing and Health Sciences, \\ Monash University, Clayton, Victoria 3168, Australia \\ 3 Institute of Biochemistry, Christian-Albrechts-University, D-24098 Kiel, Germany \\ * Correspondence: Brendan.Jenkins@hudson.org.au; Tel.: +61-3-8572-2740
}

Received: 1 July 2019; Accepted: 17 August 2019; Published: 21 August 2019

check for

\begin{abstract}
Lung cancer is the leading cause of cancer-related mortality, which histologically is classified into small-cell lung cancer (SCLC) and non-small cell lung cancer (NSCLC). NSCLC accounts for approximately $85 \%$ of all lung cancer diagnoses, with the majority of patients presenting with lung adenocarcinoma (LAC). KRAS mutations are a major driver of LAC, and are closely related to cigarette smoking, unlike mutations in the epidermal growth factor receptor (EGFR) which arise in never-smokers. Although the past two decades have seen fundamental progress in the treatment and diagnosis of NSCLC, NSCLC still is predominantly diagnosed at an advanced stage when therapeutic interventions are mostly palliative. A disintegrin and metalloproteinase 17 (ADAM17), also known as tumour necrosis factor- $\alpha$ (TNF $\alpha$ )-converting enzyme (TACE), is responsible for the protease-driven shedding of more than 70 membrane-tethered cytokines, growth factors and cell surface receptors. Among these, the soluble interleukin-6 receptor (sIL-6R), which drives pro-inflammatory and pro-tumourigenic IL-6 trans-signaling, along with several EGFR family ligands, are the best characterised. This large repertoire of substrates processed by ADAM17 places it as a pivotal orchestrator of a myriad of physiological and pathological processes associated with the initiation and/or progression of cancer, such as cell proliferation, survival, regeneration, differentiation and inflammation. In this review, we discuss recent research implicating ADAM17 as a key player in the development of LAC, and highlight the potential of ADAM17 inhibition as a promising therapeutic strategy to tackle this deadly malignancy.
\end{abstract}

Keywords: lung cancer; tobacco smoking; KRAS; EGFR; ADAM17; IL-6 trans-signaling

\section{Introduction}

Lung cancer is the primary culprit of cancer-related deaths among men and the second leading cause of cancer mortality among women worldwide, accounting for approximately $19 \%$ of all cancer deaths [1]. It is estimated that 1.8 million lung cancer cases are diagnosed each year worldwide [2]. Lung cancer is a heterogeneous disease which can be histologically classified into two major pathologies, small-cell lung cancer (SCLC) and non-small cell lung cancer (NSCLC), with the latter accounting for $85 \%$ of all lung cancer diagnoses. NSCLC is sub-classified histologically into lung adenocarcinoma (LAC), squamous-cell carcinoma and large-cell carcinoma, among which LAC is the most common form of NSCLC [3].

Although the past two decades have seen fundamental progress in the treatment and diagnosis of NSCLC, NSCLC is still often diagnosed at an advanced stage when therapeutic interventions are mostly palliative $[4,5]$. Typically, patients who are diagnosed with stage I, II and IIIA NSCLC 
undergo resection surgery to remove the tumour, followed by adjuvant therapy including radiation, chemotherapy and/or targeted therapy to prolong patient survival [4]. The first-line treatment for stage IV NSCLC patients is the non-selective chemotherapy cocktail of a platinum-based drug (Cisplatin or Carboplatin) with Paclitaxel, Gemcitabine, Docetaxel, Vinorelbine, Irinotecan, or Pemetrexed [4]. However, despite these strategies, the predicted 5-year survival rate for patients diagnosed with NSCLC is $15.9 \%$, and has only slightly improved in recent decades [5,6]. Nonetheless, recent advances in genetic testing and biomarker discovery promise to foster the new age of drug development in the context of immunotherapies and personalised medicine to replace the old non-selective chemotherapy, and thus improve treatment outcomes [4].

\section{Lung Cancer Risk Factors}

\subsection{Genetic}

\subsubsection{KRAS Mutations}

The family of RAS genes (KRAS, HRAS, and NRAS) are the first oncogenes identified, and are the most frequently mutated genes in human cancer cells, including lung, pancreatic and colorectal cancers [7]. In 1984, Santos et al., reported that mutations in KRAS are present in tumour tissues from lung carcinoma patients but not normal tissues [8]. Following this discovery, oncogenic KRAS mutations were identified as a common feature of LAC (accounting for $33 \%$ of all LAC patients) and other human cancers [3,9]. KRAS mutations are associated with tobacco smoking, and are critical for the initiation and the maintenance of LAC $[10,11]$. Experimental studies have shown that deletion of mutant Kras RNA resulted in apoptotic regression of both the early proliferative lesions and established lung tumours [10].

The RAS genes encode a family of membrane-bound guanosine triphosphate (GTP)-binding proteins that transduce signals between cell surface growth factor receptors and intracellular signaling pathways, and exist as binary molecular switches in two forms: GDP-bound (OFF or inactive) or GTP-bound (ON or active), both of which bind differentially to distinct intracellular effectors. The GDP-GTP conversion is tightly controlled by guanine nucleotide exchange factors (GEFs; which mediate GDP to GTP conversion) and GTPase-activating proteins (GAPs; which facilitate GTP to GDP conversion) $[12,13]$. RAS proteins share the same structure of the catalytic domain (i.e., G-domain), while they differ in their C-terminal hypervariable regions [13]. They undergo post-translational modifications including farnesylation, proteolytic cleavage of the C-terminus, carboxymethylation, ubiquitination, nitrosylation and palmitoylation, which are important in plasma membrane localization and interaction with their intracellular cooperators [13]. RAS mutations inhibit GAP-induced GTP hydrolysis (i.e., inactivation) of RAS proteins, resulting in their accumulation in an ON/active state [7].

RAS proteins regulate cell proliferation, differentiation, and apoptosis by interacting with signal transduction mediators, including rapidly accelerated fibrosarcoma (RAF), mitogen-activated protein kinase (MAPK), signal transducer and activator of transcription (STAT), phosphoinositide 3-kinase (PI3K), protein kinase C (PKC) and Ral guanine nucleotide dissociation stimulator (RalGDS) signaling cascades [14] (Figure 1). Moreover, oncogenic RAS proteins mediate amino acid uptake and synthesis, protein synthesis, as well as glucose uptake and metabolism [15,16]. Interestingly, analysis of 92 cell lines (including $64 K R A S$ mutant lines) from different disease settings using arrayed combinatorial small interfering RNA (siRNA) screens demonstrated that each cell line has a distinctive dependency on KRAS effectors (for example, RAF/MEK/ERK, PI3K/AKT or RAL effector pathways), with the majority of KRAS mutant cell lines being strongly dependent on either the RAF/MAPK pathway or the p90 ribosomal S6 kinases (RSKs) [17]. 


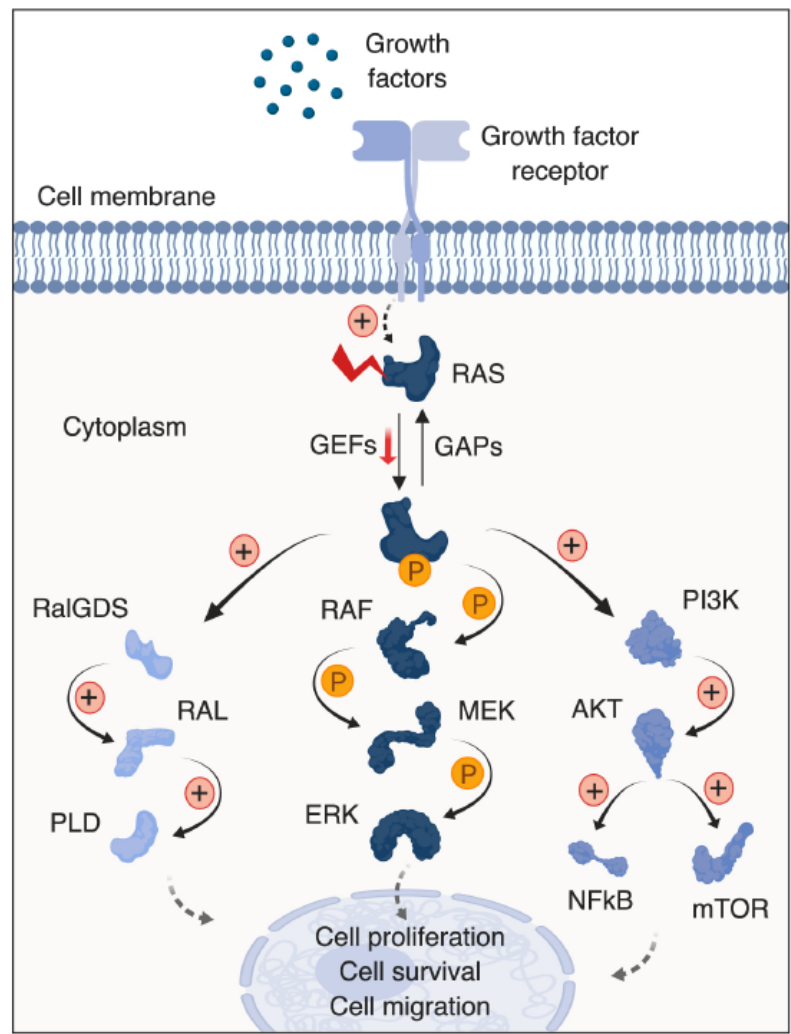

Figure 1. Signaling pathways engaged by RAS proteins. RAS mutations inhibit GAP-induced GTP hydrolysis, resulting in accumulation of active RAS. Abbreviations denote: GAPs; GTPase-activating proteins, GEFs; guanine nucleotide exchange factors, RalGDS; Ral guanine nucleotide dissociation stimulator, RAL; RAS-related protein, PLD; phospholipase D, RAF; rapidly accelerated fibrosarcoma, MEK; Mitogen-activated protein kinase kinase, ERK; extracellular signal-regulated kinase, PI3K; phosphoinositide 3-kinase, NF-кB; nuclear factor kappa-light-chain-enhancer of activated B cells and mTOR; mammalian target of rapamycin.

Many strategies have been developed over recent decades to target oncogenic RAS proteins, including targeting GDP/GTP binding and conversion, enhancing GTP hydrolysis/inactivation, inhibiting RAS post-translational modifications (i.e., farnesylation), and direct blocking of the downstream cooperators of RAS, such as RAF, MAPK, PI3K and RalGDS [13,18]. However, these therapeutic strategies have been unsuccessful due to many reasons; for instance, challenges in creating small molecules that are effective and selective to certain targets, the functional redundancy in RAS activation and its post-translational modifications, the activation of compensatory oncogenic pathways in response to RAS blockade, and the poor therapeutic index of such inhibitors [7]. As a consequence, tumours bearing $R A S$ mutations are considered the most difficult to treat and are often excluded from treatment with targeted therapies [13]. However, to overcome this issue, recent studies have reported that preventing RAS-effector protein binding by developing small-molecule pan-RAS inhibitors or disrupting KRAS dimerization may represent therapeutic strategies to impair the oncogenic properties of KRAS, albeit yet unproven in preclinical cancer models [19,20]. Furthermore, the KRAS protein and DNA vaccines have emerged as a novel immunotherapeutic strategy to tackle oncogenic KRAS-addicted cancers in preclinical models or as adjuvant treatment options in clinical settings. For instance, the administration of such vaccines enhances antigen-specific cytotoxic $\mathrm{T}$ lymphocyte responses in vitro and in vivo, resulting in antitumor effects against KRAS-driven pancreatic and lung cancers [21-23]. The adoptive transfer of T-cells harbouring the engineered T-cell receptors (TCR) that specifically recognise mutated KRAS variants G12V and G12D has also been proven effective in reducing tumour growth in a KRAS mutant xenograft model [24]. 
In addition to attempts to directly target KRAS, another promising approach is to identify and inhibit novel downstream cooperators of RAS proteins without triggering the activation of other oncogenic mechanisms. In this regard, although the MEK/ERK pathway is not hyper-activated in RAS mutant human cancer cells, as indicated by steady-state levels of pMEK or pERK, MEK or ERK inhibition has been seen as an attractive way to treat RAS mutant cancers. However, in advanced NSCLC patients (incorporating KRAS mutant LAC), the systemic blockade of the ERK MAPK pathway with MEK inhibitors trametinib and selumetinib, used either as a monotherapy or in combination with standard chemotherapy (i.e., docetaxel), has yielded limited clinical benefit associated with acquired resistance and an unfavourable toxicity profile [25]. Furthermore, inhibition of SHP2 (also known as PTPN11), which links receptor tyrosine kinase signaling to the RAS-RAF-MEK-ERK pathway, in combination with MEK inhibitors has been shown to be effective in reducing tumour growth and preventing resistance to MEK inhibitors (i.e., trametinib) in preclinical models of cancer, including pancreatic cancer and NSCLC [26-28]. Furthermore, our group has recently shown that genetic and therapeutic targeting of the ADAM17 protease significantly abrogated LAC development via inhibiting ERK1/2 MAPK activation in LAC mouse models and xenografts [29]. Interestingly, ADAM17 inhibition did not lead to any compensatory over-activation of other oncogenic pathways, such as JAK/STAT and PI3K/AKT [29]. The role of the protease ADAM17 in cancer development will be discussed in detail in later sections of this review.

\subsubsection{EGFR Mutations}

The epidermal growth factor receptor (EGFR) tyrosine kinase family was the first growth factor receptor family to be identified in cancer cells. It consists of four members, EGFR (ErbB1/Her1), Her2/neu (ErbB2), Her3 (ErbB3) and Her4 (ErbB4) [30]. Structurally, they are composed of an extracellular ligand-binding domain, a single membrane-spanning domain, a nuclear localization signal, and a cytoplasmic tyrosine kinase domain [31]. EGFR activation is regulated by the availability and the specificity of EGF family ligands, which are produced as cleavable cell surface precursor proteins and divided into three distinct groups, as follows. Firstly, EGF, transforming growth factor- $\alpha$ (TGF- $\alpha$ ), epigen and amphiregulin bind exclusively to EGFR. Secondly, betacellulin, heparin-binding EGF (HB-EGF) and epiregulin bind to both EGFR and ErbB4. Thirdly, neuregulins (NRG1/2) bind ErbB3 and ErbB4, while NRG3/4 only bind to ErbB4 [30,31]. ErbB2 has no known ligand, and by heterodimerization, it assists in the ligand-activation of other family members [32]. For all EGFR family members with known ligands, ligand binding to the extracellular domains instigates conformational changes leading to receptor homodimerization or heterodimerization with other family members at the plasma membrane, allowing for the activation of the intrinsic receptor tyrosine kinase, which causes autophosphorylation of the cytoplasmic tails of the receptors [33]. The exception to this latter mechanism of activation is ErbB3, which signals only through heterodimerization with other family members as it lacks intrinsic kinase activity [34]. Upon ligand activation, ErbB4 is cleaved by membrane proteases, while its activated intracellular kinase domain translocates to the nucleus to control gene expression [35].

Collectively, ligand binding to EGFR family members regulates a plethora of cellular processes, including cell proliferation, survival, migration and angiogenesis, via activating a myriad of signaling pathways, for example, RAS/RAF/MEK/ERK, PI3K/AKT, Src tyrosine kinases, PKC, $\beta$-catenin and STATs [30,33]. It is, therefore, perhaps not surprising that dysregulated expression and/or activity of EGFR is observed in various epithelial cancers and is associated with poor patient survival. Such cancers include head and neck squamous-cell carcinoma (HNSCC) [36,37], NSCLC [38,39], colorectal cancer (CRC) [40,41], breast cancer [42], pancreatic cancer [43], ovarian cancer [44], gastric cancer [45], and brain cancer and glioblastomas $[46,47]$. With respect to lung cancer, EGFR mutations are present in $14 \%$ of all LAC patients, and are mutually exclusive with KRAS mutations [9]. Unlike KRAS mutations that are linked to smoking, those of EGFR predominantly arise in never-smokers, with a preponderance in female LAC patients from East Asia [11,48]. 
In 1993, Rusch and colleagues demonstrated that the protein expression of EGFR is significantly increased in $45 \%$ of tumour lesions from NSCLC patients, while TGF $\alpha$ was overexpressed in $61 \%$ of those tumours. These overexpression patterns were not detected in the adjacent normal tissues, suggesting that EGFR signaling is playing a role in developing NSCLC tumours [38]. This notion has paved the way for the development of orally-active EGFR tyrosine kinase inhibitors (TKIs), for example, Gefitinib (Iressa ${ }^{\circledR}$ ), which binds the adenosine triphosphate (ATP) pocket in the EGFR catalytic domain without affecting insulin receptor tyrosine kinase activity, as a first-line targeted therapy for NSCLC $[49,50]$. In 2004, two landmark studies identified a causal role of EGFR mutations in NSCLC, where EGFR mutations correlated with patient responsiveness to Gefitinib therapy, and also, with growth inhibition by Gefitinib in NSCLC cell lines [39,51]. The role of those mutations was also confirmed in 'never smokers' patients with adenocarcinomas [52]. These EGFR mutations are heterozygous by nature and include small in-frame deletions and missense substitutions, which were shown to selectively activate PI3K/Akt and STAT signaling pathways, thus promoting cell survival and resisting cell apoptosis [53]. Moreover, EGFR mutations mediate the repositioning of critical residues juxtaposing the ATP-binding pocket of the tyrosine kinase domain of EGFR, resulting in stabilizing the interactions of the receptor with both ATP and TKIs [39,51].

Since EGFR signaling is implicated in the growth and progression of many cancers, a significant effort has been made to understand the full spectrum of its action in promoting cancer, thus informing the development of EGFR-targeted therapies. Monoclonal antibodies such as Cetuximab $\left(\right.$ Erbitux ${ }^{\circledR}$ ) and Panitumumab (Vectibix ${ }^{\circledR}$ ) have been developed to target the extracellular domain of EGFR or to block EGF and TGF $\alpha$-induced activation of EGFR. These antibodies were FDA approved for use as monotherapy or in combination with other chemotherapies or radiation to treat HNSCC and CRC [54-58]. However, the use of monoclonal antibodies has been hampered by the development of antibody-dependent cell-mediated cytotoxicity [31]. EGFR TKIs were also developed as low-molecular-weight synthetic molecules that block the ATP binding pocket of the intracellular tyrosine kinase domain, which inhibits ligand-induced receptor autophosphorylation, leading to dampening of EGFR-dependent intracellular downstream signaling [31]. Several TKIs have been developed including Gefitinib (Iressa ${ }^{\circledR}$ ), Erlotinib (Tarceva ${ }^{\circledR}$ ), Lapatinib (Tykerb ${ }^{\circledR}$ ) and Vandetanib $\left(\right.$ Caprelsa ${ }^{\circledR}$ ) for the treatment of various malignancies, including HNSCC, NSCLC, breast cancer and CRC [31,59-61]. Moreover, the response of patients to TKIs (e.g., Gefitinib) is temporary with little to no longer-term clinical benefits due to tumours developing acquired drug resistance via secondary EGFR mutations or shifting their oncogenic dependence to EGFR-independent oncogenic pathways, including the KRAS/RAF/ERK pathway [31,62,63].

Taken together, these current limitations in targeting EGFR for long-term clinical benefit, plus the fact that effective therapies for NSCLC with mutation profiles typical for cigarette smoking are yet to be identified [31,62], highlight the urgent medical need to identify novel molecular targets to tackle NSCLC and other cancers.

\subsection{Cigarette Smoking}

Inhalation of environmental noxious particles has been proven to play a role in several lung diseases, including lung cancer and chronic obstructive pulmonary disease (COPD). Tobacco smoke, a well-known noxious agent and a pivotal risk factor for the development of lung cancer, is the leading preventable cause of mortality [64]. The association between lung cancer and cigarette smoking is unequivocal, with the trend of lung cancer incidence rates in a given country strongly aligned to its relative tobacco use [2]. However, the majority of smokers do not develop lung cancer, indicating that genetic, epigenetic and cellular factors including inflammation, oxidative stress, cellular senescence and injury may modulate the response of the lungs to noxious agents and determine the risk for developing lung neoplasia [64].

Exposure to tobacco smoke constituents instigates a cascade of events in the multistep process leading to pulmonary carcinogenesis [65]. Among the plethora of chemicals in cigarette smoke 
that are implicated in pulmonary carcinogenesis, the most carcinogenic compounds chemically belong to two groups: (1) polycyclic aromatic hydrocarbons and (2) nitrosamines. Moreover, the key ingredient, nitrosamine 4-(methylnitrosamino)-1-(3-pyridyl)-1-butanone, also known as nicotine-derived nitrosamine ketone (NNK), plays a crucial role in lung carcinogenesis [66]. NNK is a product of nicotine nitrosation during tobacco production and as a result of mammalian metabolism [67]. NNK levels in mainstream smoke (which originates from burning the cigarette) are 10-200 ng per cigarette, while its levels in sidestream smoke (exhaled by the smoker) are 50-100 ng per cigarette [68]. NNK is also implicated in thirdhand tobacco smoke, where it has been identified on the surfaces and in the dust of areas where smoking took place [69].

The carcinogenicity of NNK has been demonstrated in rats [70], Syrian golden hamsters [71], and mice [72,73]. In mice, NNK reproducibly induces bronchioalveolar hyperplasia, adenoma and adenocarcinoma in the lungs [73]. Moreover, NNK potentiates lung tumourigenesis in several genetically engineered mouse strains, such as the G-protein coupled receptor 5A (Gprc5a) knock-out mice [74], SPC/Myc transgenic mice overexpressing c-Myc [75], Clara (Club) cell protein CC10 knock-out mice [76], and the SPC/IgEGF transgenic mice overexpressing a soluble form of EGF [75].

At the molecular level, NNK metabolites are potent mutagens that induce activating mutations in the Kras proto-oncogene (due to the GC-to-AT transition at the second base of codon 12) and inactivating mutations in the Trp53 tumour suppressor [73,77]. NNK induces the formation of the O-methylguanine adduct within ATII cells, resulting in Kras gene activation, followed by proliferation of ATII cells and malignant tumour formation [73]. Non-malignant human bronchial epithelial cells (HBECs) exposed to NNK in vitro also show malignant transformation with altered production of reactive oxygen species (ROS) and redox regulation [78]. NNK also induces cancer cell proliferation through engaging various signal transduction molecules and transcription factors, including ERK1/2 MAPK, p38 MAPK, PI3K/AKT, NF-kB, cyclooxygenase-2 (COX-2), B-cell lymphoma 2 (Bcl2) and c-Myc [79-84] (Figure 2). Despite the diversity of downstream effector molecules engaged by NNK, the full spectrum of molecular events which underpin its pulmonary oncogenicity remains unresolved.

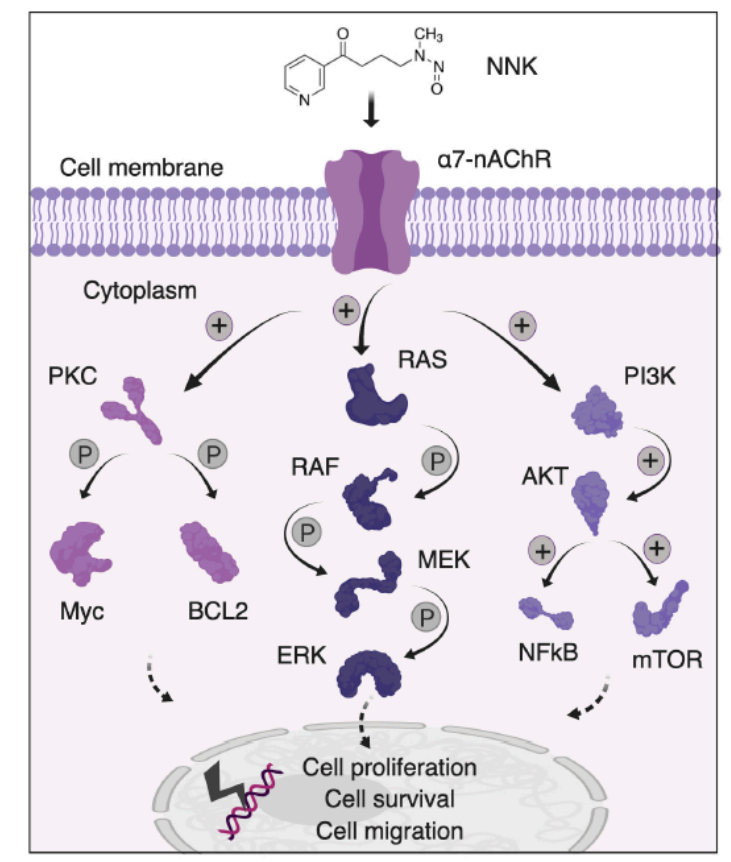

Figure 2. NNK-mediated activation of oncogenic signaling pathways. Abbreviations denote: NNK, nicotine-derived nitrosamine ketone; $\mathrm{nAChR}$, nicotinic acetylcholine receptors; $\mathrm{PKC}$, protein kinase $\mathrm{C}$; BCL2, B-cell lymphoma-2; RAF, rapidly accelerated fibrosarcoma; MEK, mitogen-activated protein kinase kinase; ERK, extracellular signal-regulated kinase; PI3K, phosphoinositide 3-kinase; NF- $\mathrm{B}$, nuclear factor kappa-light-chain-enhancer of activated B cells; mTOR, mammalian target of rapamycin. 


\subsection{Inflammation}

There is accumulating evidence that the pathogenesis of lung cancer is associated with inflammation, particularly among cigarette smokers [85] (Table 1). A major risk factor for the development of lung cancer among smokers is COPD, which is manifested by persistent inflammation, oxidative stress, airway remodelling and injury of lung parenchyma [64]. The tumour immune microenvironment, comprising mainly of innate immune cells (macrophages and neutrophils), adaptive immune cells (B-cells and T-cells) and fibroblasts, has critical roles in dictating the characteristics of lung and other tumours, either by promoting chronic inflammation and tumourigenesis, or conversely delaying malignant progression via mounting of an anti-tumour immune response [86,87].

Poor prognosis in NSCLC has been associated with increased neutrophil accumulation in bronchoalveolar lavage fluid and in the alveolar lumen [88]. Alveolar macrophages have also been shown to play an important role in promoting lung carcinogenesis. Indeed, long-term depletion of macrophages markedly reduced tumour burden in a model of urethane-induced lung carcinogenesis [89]. Tumour-associated macrophages secrete pro-tumourigenic angiogenic factors, such as platelet-derived growth factor (PDGF) and vascular endothelial growth factor (VEGF), that fuel tumour cells and their growth $[89,90]$. Kras activation in Club (Clara) cells residing in the bronchiolar epithelium also induces a fulminant inflammatory response manifested by an abundant infiltration of alveolar macrophages and neutrophils [91]. In addition to these innate immune cells, adaptive immune IL-17-positive CD4 T cells and regulatory T cells are also associated with the development of lung cancer [92]. Recently, commensal microbiota were shown to instigate inflammation in LAC via activating lung-resident $\gamma \delta$ T cells. In this scenario, local bacteria induce MyD88-dependent IL-1 $\beta$ and IL-23 secretion from myeloid cells, thus enhancing the proliferation and activation of $\gamma \delta \mathrm{T}$ cells, which induce IL-17-mediated inflammation and tumour cell proliferation. Eradication of these bacteria using germ-free mice or treatment with antibiotics markedly abrogated lung cancer development in a mouse model harbouring Kras mutation and Trp53 deficiency [93].

Pro-inflammatory cytokines have also been implicated in the development of lung cancer (Table 1). IL-17 induces in vivo growth of NSCLC xenografts via promoting the net angiogenic activity and vascularity of tumour cells [94]. IL-6 can be secreted from RAS and EGFR mutant cells to promote tumourigenesis, an effect that has been attributed to IL-6 trans-signaling via the sIL-6R in Kras mutant LAC $[95,96]$. Indeed, the knockdown or blockade of IL-6 signaling using genetic approaches or neutralising antibodies abrogates RAS and EGFR-driven tumourigenesis via suppressing STAT3 activation [95-97]. Also, IL-8 expression is up-regulated in NSCLC cell lines and tumour biopsies, and corelates with impaired patient survival via promoting tumour angiogenesis [98-100]. Indeed, anti-IL-8 neutralising antibodies reduced tumour growth and metastasis in a xenograft model of NSCLC [101].

Inflammasome activation and subsequent production of IL-1 $\beta$ has also been shown to enhance tumour invasiveness, growth and metastasis [102]. Intriguingly, analysis of the Canakinumab Anti-inflammatory Thrombosis Outcomes Study (CANTOS), a randomised double-blind, placebo-controlled trial investigating the role of IL-1 $\beta$ inhibition in atherosclerosis using the selective anti-IL-1 $\beta$ monoclonal antibody Canakinumab (Ilaris ${ }^{\circledR}$ ), revealed that lung cancer incidence and mortality were significantly lower in Canakinumab-treated patients compared to their placebo controls. This study alone suggests the potential role of IL- $1 \beta$ inhibition as a promising strategy for the treatment of lung cancer $[103,104]$ (Table 1). 
Table 1. Published clinical and preclinical evidence supporting the role of inflammation in NSCLC.

\begin{tabular}{|c|c|c|c|}
\hline Factor & Main Effect & Model & Reference \\
\hline Neutrophils & Poor prognosis & Human patients & [88] \\
\hline Macrophages & Promoting lung carcinogenesis & $\begin{array}{l}\text { Urethane-induced lung cancer } \\
\text { mouse model }\end{array}$ & [89] \\
\hline IL- $17^{+} \mathrm{T}$ cells & $\begin{array}{l}\text { Enhancing tumour } \\
\text { proliferation and angiogenesis }\end{array}$ & Kras mutant mouse model & [92] \\
\hline $\begin{array}{l}\text { Commensal } \\
\text { microbiota }\end{array}$ & $\begin{array}{l}\text { induce tumour cell } \\
\text { proliferation via activating } \\
\text { lung-resident } \gamma \delta \text { T cells }\end{array}$ & $\begin{array}{l}\text { Mouse model harbouring Kras } \\
\text { mutation and Trp53 deficiency }\end{array}$ & [93] \\
\hline IL-17 & $\begin{array}{l}\text { Promoting tumour } \\
\text { angiogenesis }\end{array}$ & NSCLC xenografts & [94] \\
\hline IL-6 & $\begin{array}{l}\text { Activation of IL-6 } \\
\text { trans-signaling }\end{array}$ & Kras mutant mouse model & [95-97] \\
\hline IL-8 & $\begin{array}{l}\text { Promoting tumour } \\
\text { angiogenesis }\end{array}$ & Human patients & [98-101] \\
\hline IL-1 $\beta$ & $\begin{array}{l}\text { Enhance lung cancer incidence } \\
\text { and mortality }\end{array}$ & Human patients (CANTOS) & [103] \\
\hline
\end{tabular}

The ability of tumour cells to evade immune surveillance and facilitate tumour survival is due to their expression of surface molecules that interact with immune cells to maintain normal immune tolerance, which includes the interaction of the immune receptor programmed cell death 1 (PD1) with its tumour-associated ligand PD-L1 [6]. This interaction inhibits the anti-tumour functions of $\mathrm{T}$ cells including differentiation, proliferation and cytokine production [105]. Therefore, blockade of PD1/PD-L1 using monoclonal antibodies (e.g., Nivolumab (Opdivo ${ }^{\circledR}$ ) and Pembrolizumab (Keytruda ${ }^{\circledR}$ )) provides an attractive way to restore the body's immune system to attack tumour cells, which has been suggested as a treatment for NSCLC, particularly in PD1 high-expressing tumours [106-109]. However, the long-term clinical benefits from the use of such inhibitors are not clear [106-109]. In addition, PD-L1 has not been associated with the major driver mutations in NSCLC (KRAS and EGFR) [106-109], questioning the clinical relevance of using PD1/PD-L1 blockers in NSCLC.

\section{The ADAM Family of Proteases}

Many extracellular signaling proteins are synthesized as transmembrane proteins. The extracellular domain (ectodomain) of these proteins acts as its active form, which is shed from cells after cleavage by members of the ADAM family, which are structurally related, membrane-associated metalloproteinases [110,111] (Figure 3). The released active protein exerts its action mainly through paracrine signaling, and possibly via entering the bloodstream [112] (Figure 4). Proteolytic shedding of the ectodomain is an irreversible post-translational modification process, which controls the bioavailability of soluble signals and ligands that regulate cardinal processes including development, physiology, immunity, and pathology [110].

ADAM family members consist consecutively of an $\mathrm{N}$-terminal signal sequence, a prodomain, a catalytic metalloprotease domain, a disintegrin domain, a cysteine-rich region, EGF-like domain, a transmembrane domain, and a cytoplasmic tail [112] (Figure 5). ADAM10 and ADAM17 are the best characterised ADAMs [110,112]. Although they share overlapping specificity for a repertoire of substrates, they have substrate preferences. This may result from the distinctive characteristics of their catalytic sites, the sensitivity to cellular signals and stimuli, the time required for processing of the substrate, the subcellular localization of the protease and its substrate and/or the cellular cues and contexts [111,113-115]. 


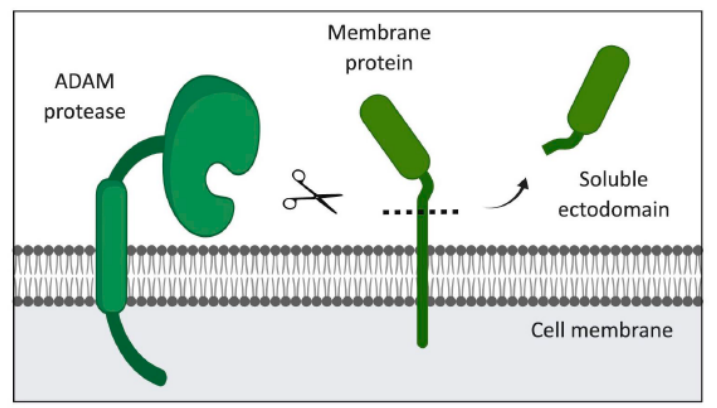

Figure 3. The role of ADAM proteases in ectodomain shedding. Membrane-bound ADAM recognizes specific cleavage site in the extracellular membrane-proximal region of membrane-tethered substrates, following which, it enzymatically cleaves substrates to facilitate their release as biologically active soluble ectodomains.

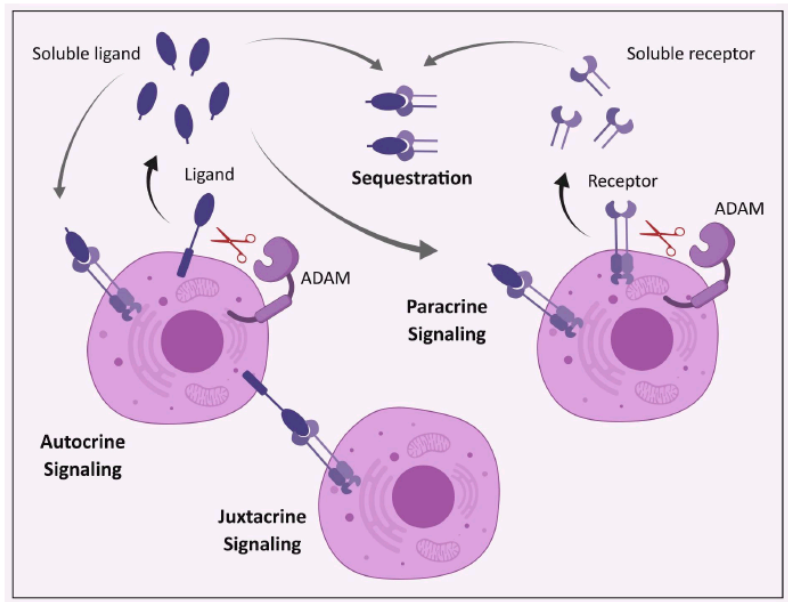

Figure 4. Modes of action of ectodomain proteins. Schematic representation of the various autocrine, paracrine and/or juxtacrine modes of action by which biologically active processed ADAM17 substrates (i.e., ectodomains) act on cells.

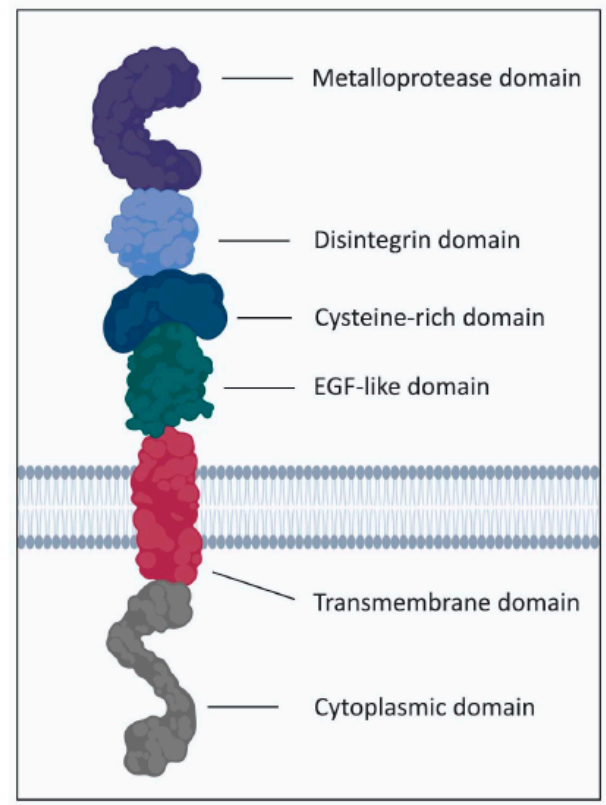

Figure 5. Overview of the domain structure of ADAM proteases. 


\subsection{ADAM17}

In 1997, two research groups reported ADAM17 as the TNF $\alpha$ converting enzyme (i.e., TACE) that releases bioactive TNF $\alpha$ from cells $[116,117]$. Since then, it has been shown that ADAM17 is responsible for the shedding of more than 70 membrane-tethered cytokines, growth factors, and cell surface receptors including sIL-6R, Notch receptor and EGFR ligands [118] (Figure 6). Therefore, ADAM17 is a pivotal switch for a myriad of physiological and pathological processes including cell proliferation, regeneration, differentiation, inflammation and cancer progression [118]. Moreover, ADAM17 is required for the normal development of various organs including the heart valves [119], eye, skin, hair, lungs $[120,121]$ and mammary glands [122]. ADAM17 is ubiquitously expressed in human lung tissue [123], and its expression is up-regulated in lung diseases including asthma, COPD and endotoxin-induced acute lung injury [123-125].

\begin{tabular}{|c|c|c|c|c|c|c|c|}
\hline \multicolumn{5}{|c|}{ Immunity and Inflammation } & \multicolumn{3}{|c|}{ Cell adhesion } \\
\hline \multirow{5}{*}{$\begin{array}{l}\text { Notch1 }^{*} \\
\text { Jagged } \\
\text { DLL1 }\end{array}$} & $\mathrm{TNFa}^{*}$ & Lympho & toxin a & LAG-3 & L-Selectin & SynCAM & \\
\hline & TNFR1 & $\mathrm{IL}^{-1 \mathrm{R}_{\|}}$ & TIM-4 & M-CSFR & ICAM-1 & Nectin-4 & \\
\hline & TNFR2 & IL-6R* & CX3CL1 & LDL-R & NCAM & EpCAM & \\
\hline & & IL-15R & CD16 & SORL1 & VCAM-1 & JAM-A & \\
\hline & & RANKL & CD30 & SORT1 & L1CAM & CD44 & \\
\hline $\mathrm{KL}-1$ & NRG1* & TIM-1 & CD36 & SORCS1 & Desmogle & in 2 & Muc-1 \\
\hline $\mathrm{KL}-2$ & HER4* & TIM-3 & CD40 & SORCS3 & Coll & XVII & NPR \\
\hline GHR & EREG & & CD89 & CSF-1 & M & & ACE-2 \\
\hline IGF2R & TrkA & & CD91 & ICOSL & & & Ptprz \\
\hline VEGFR2 & Syndecar & & CD163 & MIC-A & & GP1ba & GPV \\
\hline FLT-3L & Syndecar & & & MIC-B & & APP & GP-1a \\
\hline Amphire & gulin* & & & & & EPCR & \\
\hline EGF* & LYPD3 & & & & & Preadip & cyte \\
\hline HB-EGF & PMEL17 & & & & & factc & \\
\hline $\begin{array}{l}\text { TGFa }^{\star} \\
\text { Epigen }\end{array}$ & TMEFF2 & $\begin{array}{l}\text { develop } \\
\text { differe }\end{array}$ & $\begin{array}{l}\text { eration, } \\
\text { ment and } \\
\text { entiation }\end{array}$ & & & Other fun & ctions \\
\hline
\end{tabular}

Figure 6. ADAM17 substrate repertoire. Shown are the $>70$ known ADAM17 substrates grouped according to their implicated role in numerous cellular processes (highlighted in bold blue font). ADAM17 substrates associated with lung cancer are denoted in bold font and by an asterisk.

Investigating the role of ADAM17 in health and disease in vivo has been challenging, since homozygous Adam17 gene deletion results in perinatal lethality [120,126]. To overcome this, viable conditional ADAM17 knockout mice models that lack ADAM17 in certain compartments have been generated, for example, endothelial cells or leukocytes [127,128]. Moreover, radiation chimeric mice reconstituted with ADAM17 $\triangle \mathrm{Zn} / \Delta \mathrm{Zn}$ hematopoietic cells, that lack functional ADAM17 due to targeted deletion of exon 11 harbouring its $\mathrm{Zn}^{2+}$-binding domain, have been used to demonstrate the pivotal role of ADAM17 in the shedding of leukocyte substrates [129]. Furthermore, a new strategy has been reported to generate viable mice with undetectable ADAM17 levels, which involved the creation of the Adam17ex allele via inserting a new exon into the Adam 17 gene, which started with an in-frame translational stop codon [130]. The new exon was flanked by altered canonical splice donor/acceptor sites, yielding a new artificial exon between exons 11 and 12, which when used, led to an abort of translation. Due to the non-canonical splice sites, the new exon was primarily used, leading to about $5 \%$ of ADAM17 expression compared to wild-type animals (Figure 7). The homozygous Adam $17^{\text {ex/ex }}$ mice exhibited eye, skin and heart defects with reduced levels of soluble ADAM17 substrates [130]. The Adam $^{\mathrm{x} / \mathrm{ex}}$ mice have been used extensively to identify the role of ADAM17 in inflammation and cancer [29,130-132]. 


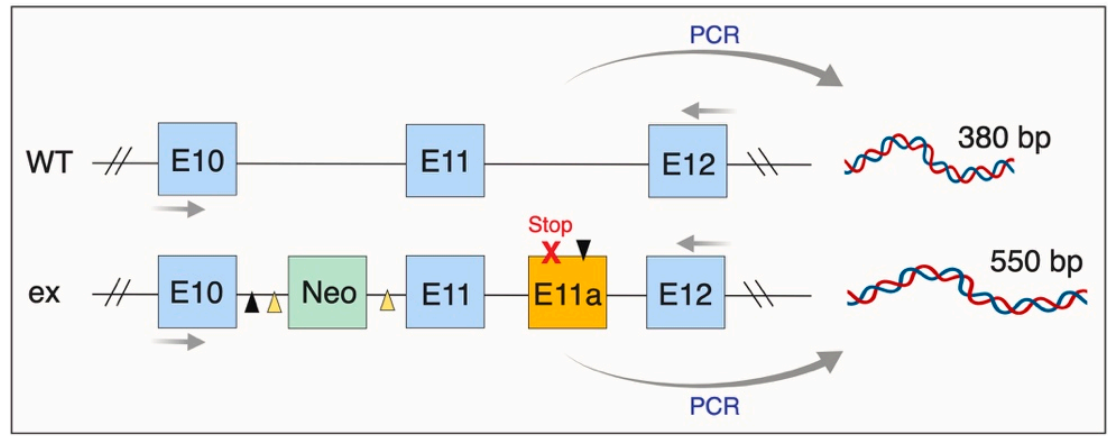

Figure 7. Overview of the genetic manipulation strategy used to create the Adam $17^{\mathrm{ex} / \mathrm{ex}}$ mice. Shown are the exon regions for both wild-type (WT) and hypomorphic (ex) Adam17 alleles. For generating the ex allele, the neomycin resistance gene in the targeting cassette is depicted "Neo", along with the introduced stop codon in the artificial exon 11 (E11a). Arrows depict PCR primers use to amplify and distinguish specific regions of the WT and ex alleles.

\subsection{Regulation of ADAM17 Activity}

The sheddase activity of ADAM17 can be stimulated by a variety of stimulatory agents and signaling pathways, including phorbol ester, phorbol 12-myristate 13-acetate (PMA) [133], cytokines including TNF $\alpha$, interferon $\gamma$ (IFN $\gamma$ ) and IL-1 $\beta$ [113,134,135], Toll-like receptors (TLRs) [136], and G-protein coupled receptors (GPCR) [137]. Although ADAM17 activation has been studied extensively since it has been discovered, the molecular mechanisms by which cell signals stimulate ADAM17 have remained ambiguous. Indeed, how ADAM17 is activated is still puzzling molecular biologists, and the complexities of its regulation have been reported extensively previously $[118,138,139]$, and for this reason, will only be briefly discussed below.

ADAM17 is synthesized as a catalytically inactive full-length precursor in the endoplasmic reticulum (ER). In the trans-Golgi network, this pro-form of ADAM17 undergoes a maturation step, which requires its inhibitory N-terminal prodomain—acting as a molecular chaperone for ADAM17-to be cleaved off by pro-protein convertase (furin protease), resulting in a catalytically active mature form of ADAM17 [140,141]. ADAM17 prodomain has been shown to interact and inhibit the catalytic domain of ADAM17, thus abrogating specifically ADAM17 surface activity [142]. Indeed, a stable form of the ADAM17 prodomain attenuated ADAM17-mediated disease models of sepsis, rheumatoid arthritis and inflammatory bowel disease via inhibiting $\mathrm{TNF} \alpha$ secretion, thus providing in vivo evidence as a potential new highly selective inhibitor of ADAM17 [143]. Moreover, as will be discussed below, the ADAM17 prodomain can also mitigate LAC via selectively inhibiting sIL-6R shedding [29] (Figure 8).

The rhomboid protease family members (iRhoms), which are polytopic non-catalytic rhomboid-like intramembrane proteases, have emerged as critical regulators of constitutive and inducible shedding activity of ADAM17 [144-148]. Indeed, mouse embryonic fibroblasts (MEFs) lacking both iRhom1 and iRhom 2 are devoid of ADAM17 shedding activity [144,146]. iRhom2 has been reported to mediate the trafficking of ADAM17 from the ER, which is suggested to be the rate-limiting step for ADAM17 maturation [145], and consequently, regulating ADAM17 shedding activity [144,149]. Here, the transmembrane domain of ADAM17 is suggested to be required for the binding of ADAM17 to iRhom2 [144]. Further evidence for a key role of iRhom2 in regulating ADAM17 is the observation that while functional ADAM17 has been detected in exosomes, inhibition of iRhom2 suppressed exosomal ADAM17 release [150] (Figure 8). 


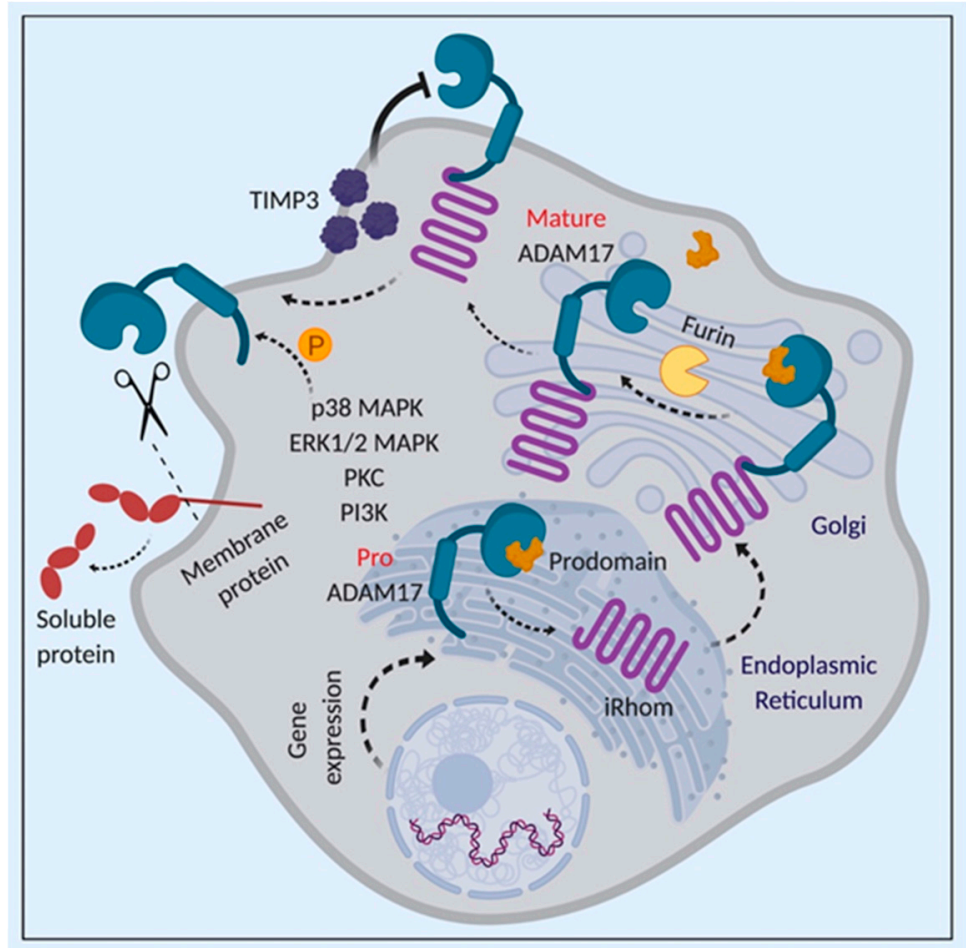

Figure 8. Overview of ADAM17 activity regulation. Schematic representation of the expression of immature proADAM17 polypeptide in the endoplasmic reticulum, following which it is transported to the golgi apparatus via iRhom-mediated mechanism. The proADAM17 then undergoes a maturation step, which requires its inhibitory N-terminal prodomain to be cleaved off by furin protease, following which, mature ADAM17 is transported to the cell membrane. The activity of ADAM17 can also be inhibited by TIMP3 or activated via phosphorylation by MAPKs, PI3K and PKC.

The phosphorylation of the cytoplasmic domain of ADAM17 also plays a pivotal role in controlling its sheddase activity. Specifically, phosphorylation of Threonine 735 residue $\left(\mathrm{Thr}^{735}\right.$ ) by MAPKs, including ERK and p38 MAPK, can enhance ADAM17 shedding activity, and this ERK-mediated Thr ${ }^{735}$ phosphorylation can also induce ADAM17 trafficking to the cell membrane [151-155] [156]. Of note, cellular senescence is associated with ADAM17-mediated release of amphiregulin and TNF receptors from the surface of senescent cells via p38 MAPK-induced phosphorylation of ADAM17 cytoplasmic tail [157]. Interestingly, p38 (but not ERK) has been shown to phosphorylate (i.e., activate) ADAM17 on $\mathrm{Thr}^{735}$, thus enhancing its shedding of the pro-tumourigenic and pro-inflammatory sIL-6R in LAC models [29].

Another regulatory mechanism of ADAM17 activity involves tissue inhibitor of metalloproteinases-3 (TIMP3), which inhibits ADAM17 activity via interacting with its ectodomain [158,159]. Indeed, genetic ablation of TIMP3 enhances ADAM17 activity and TNF $\alpha$ shedding, leading to inflammation [160]. The activity of ADAM17 can also be regulated via dimerization involving its cytoplasmic domain (also required for its interaction with TIMP3), and ADAM17 can be present as dimers at the cell surface during steady states [154]. With respect to the above-mentioned regulation by MAPKs, upon activation by ERK or $\mathrm{p} 38$ MAPK signaling, ADAM17 dimers dissociate and ADAM17 is presented as monomers, allowing for the release of TIMP3 [154].

Other mechanisms of regulating ADAM17 activity include the disruption of the actin cytoskeleton, probably via a mechanism independent of p38 MAPK or ERK-induced ADAM17 phosphorylation [161]. In this scenario, the actin-binding protein, filamin, has been proposed to regulate ADAM17 activity since disrupting the ADAM17-filamin interaction inhibited ectodomain shedding of CD44 and amyloid protein precursor [162]. Additional mechanisms of ADAM17 regulation, albeit ill-defined, involve the tetraspanin CD9, redox modifications of the cysteinyl sulfhydryl groups in mature ADAM17 (i.e., 
exclusive of its prodomain and intracellular region), and PKCE [163-165]. ADAM17 activity could also be regulated during its transport to Golgi apparatus by sequestering in lipid rafts, since depletion of membrane cholesterol enhances ADAM17-dependent shedding of TNF $\alpha$ and TNF receptors [166].

Interestingly, Dang et al. has proposed that ADAM17 substrate selectivity may be modulated by certain signaling pathways in response to the inducers PMA and angiotensin II, irrespective of enhanced ADAM17 protease activity [167]. Activation of PKC- $\alpha$ and the PKC-regulated protein phosphatase 1 inhibitor 14D is required for ADAM17 cleavage of TGF- $\alpha$, HB-EGF and amphiregulin, while PKC- $\delta$ is required for NRG release [167]. Moreover, a juxtamembrane segment in the extracellular domain of the ADAM17, regulated by a protein-disulfide isomerase, has been identified as a sensor that binds IL-6R, but not TNF $\alpha$, and mediates its shedding [168]. These studies indicate that substrate selection by ADAM17 could be influenced in certain settings by different mechanisms.

\section{ADAM17 and Its Role in Cancer}

Since ADAM17 mediates the ectodomain shedding of various pro-tumourigenic cytokines, growth factors and surface receptors [138], it is of no surprise that ADAM17 has attracted attention as a potential driver of cancer. In support of this notion, ADAM17 is overactivated or overexpressed in numerous human cancers, including NSCLC (and its major LAC subtype), colon carcinoma, breast cancer, hepatocellular carcinoma, HNSCC and gastric cancer [29,169-177]. Furthermore, ADAM17 targeting using genetic, antibody-mediated or pharmacological methods suppresses cell proliferation and tumour growth in cancer models for LAC [29,131], CRC [132], breast cancer [178], prostate cancer [179], pancreatic cancer [180] and ovarian cancer [181]. Some of the therapeutic agents that were developed to inhibit ADAM17 are summarized in Table 2.

Table 2. A summary of some therapeutic inhibitors of ADAM17.

\begin{tabular}{|c|c|c|c|c|}
\hline Agent & Type of Agent & Disease Setting & $\begin{array}{l}\text { Substrate } \\
\text { Inhibited }\end{array}$ & Reference \\
\hline INCB3619 & $\begin{array}{l}\text { Small molecule } \\
\text { inhibitor }\end{array}$ & $\begin{array}{c}\text { Breast cancer and } \\
\text { NSCLC }\end{array}$ & Heregulin & [182] \\
\hline INCB7839 & $\begin{array}{l}\text { Small molecule } \\
\text { inhibitor }\end{array}$ & Breast cancer & HER2 & {$[183,184]$} \\
\hline KP-457 & $\begin{array}{l}\text { Small molecule } \\
\text { inhibitor }\end{array}$ & Thrombus formation & $\begin{array}{l}\text { Glycoprotein } \operatorname{Ib} \alpha \\
(\mathrm{GPIb} \alpha)\end{array}$ & [185] \\
\hline Prodomain & Peptide & $\begin{array}{c}\text { LAC and } \\
\text { inflammatory diseases }\end{array}$ & $\mathrm{TNF} \alpha$ and IL-6R & {$[29,131,143]$} \\
\hline D1(A12) & Antibody & $\begin{array}{l}\text { Triple-negative breast } \\
\text { cancer and head and } \\
\text { neck squamous cell } \\
\text { carcinoma }\end{array}$ & $\begin{array}{c}\mathrm{TNF} \alpha, \mathrm{TGF} \alpha, \\
\text { amphiregulin and } \\
\text { TNFR1 }\end{array}$ & {$[174,186]$} \\
\hline A9(B8) & Antibody & $\begin{array}{c}\text { Pancreatic ductal } \\
\text { adenoma }\end{array}$ & Amphiregulin & [180] \\
\hline
\end{tabular}

Despite the success of targeting ADAM17 using small-molecule inhibitors (SMIs) and siRNA in cancer models, the clinical benefits of such approaches are questionable. Indeed, the caveat of using SMIs (e.g., hydroxamates such as GW280264X) to inhibit ADAM17 is their non-specificity since they target other proteases (e.g., ADAM10) leading to off-target effects and unfavourable toxicity profiles that have resulted in their failure in the clinic $[182,187,188]$. For example, potent non-selective inhibitors of ADAM17 and ADAM10, such as INCB3619 and INCB7839 (aderbasib), have shown promise in reducing tumour growth alone or in combination with other chemotherapeutic agents when tested in preclinical models of breast cancer and NSCLC [182-184,189]. However, their efficacy in the clinic has been stunted due to safety and toxicity concerns likely due to the induction of deep 
vein thrombosis in some patients [190]. The inhibitor INCB7839 is currently under investigation in the clinical trial NCT02141451, in combination with Rituximab (a monoclonal antibody targeting CD20), for the treatment of Diffuse Large B Cell Non-Hodgkin Lymphoma.

In addition, using siRNA to inhibit ADAM17 expression is problematic to translate, and is considered a questionable approach since suppressing ADAM17 expression does not necessarily affect its activity [191,192]. Similarly, transgenic over-expression of ADAM17 in mice, including in the lung, does not result in increased shedding (i.e., protease) activity, thus indicating that ADAM17 activity is not dependent on its transcriptional regulation [193]. Therefore, there is a clear need to identify and develop new non-toxic and selective inhibitors of ADAM17. In this regard, the ADAM17 prodomain has been identified as a potent inhibitor of ADAM17 surface activity, which significantly reduced tumour burden in LAC models $[29,131]$. In addition, the recent advent of specific antibodies to inhibit ADAM17 activity provides another avenue to specifically target ADAM17 whilst minimizing any off-target effects [180].

\subsection{ADAM17 and Its Substrates in Lung Cancer}

While the role of ADAM17 and its specific substrates (e.g., EGFR ligands, Notch, sIL-6R) has been previously documented in several cancers (e.g., lung cancer, CRC, pancreatic cancer, breast cancer) $[29,41-43,61,97,132,177,182,187,194-197]$, for the purpose of this review, we will focus on lung cancer, for which many mechanistic insights are relevant to other cancer types.

\subsubsection{EGFR Ligands}

The role of EGFR signaling in the pathogenesis of cancer, including the lung, is undisputable $[51,53,96,182,198-200]$. EGFR ligands have the ability to stimulate their receptors in autocrine, paracrine and juxtacrine modes [112]. It has been suggested that the uncleaved membrane-tethered EGFR ligands hinder the dimerization of the ligand-receptor pairs. Therefore, shedding of the ligand removes this impediment, resulting in enhanced dimerization and EGFR signaling [112]. Surprisingly, overexpression of uncleavable forms of TGF $\alpha$ or HB-EGF could also enhance EGFR signaling, mainly through enhancing juxtacrine signaling [201-203], and also by preventing endocytosis and down-regulation of the receptor [204]. However, it has been suggested that the transmembrane form of the ligand could activate EGFR via juxtacrine signaling only after its shedding via ADAM17 [195]. Nonetheless, these data place ADAM17 at the centre of EGFR signaling.

In the context of lung cancer, amphiregulin has been shown to inhibit cell apoptosis in NSCLC cell lines via insulin-like growth factor-1 (IGF1)-dependent mechanism [205]. In addition, tobacco smoke exposure to NSCLC cell lines can enhance ADAM17 activation, culminating in the release of amphiregulin and EGFR activation [165]. Interestingly, serum levels of amphiregulin and TGF $\alpha$ predict poor response to Gefitinib in patients with advanced NSCLC [206].

\subsubsection{Notch Signaling}

Aberrant Notch signaling has been implicated in the development of numerous human malignancies, including acute lymphoblastic leukemia, breast cancer, melanoma and LAC [196]. There are four different Notch receptors (Notch 1-4) and five ligands (Delta-like 1, 3, and 4 and Jagged 1 and 2) [196]. Notch signaling is tightly controlled via cleavage of Notch receptor at distinctive sites. Firstly, a furin-like convertase cleaves Notch receptor at the ectodomain (S1) site to create a cell surface receptor [207], which is resistant to proteases in the absence of Notch ligands [208]. Therefore, engaging the Notch ligand allows for the generation of a second proteolysis site (S2) to be processed by ADAM proteases. Subsequently, the aspartyl protease $\gamma$-secretase carries out cleavage at sites S3 and S4, producing Notch intracellular domain (NICD) and culminating in its nuclear translocation and activation of Notch target genes, including HES1 and HEY1 [209].

Although Notch1 is a substrate of both ADAM10 and ADAM17, it has been suggested that ADAM10 can only process the ligand-associated receptor, while ADAM17 cleavage activity is 
independent of Notch ligands [210]. In the context of NSCLC, Notch signaling exerts pro-oncogenic role via enhancing tumour cell survival under hypoxic conditions [211]. Furthermore, Notch1 deficiency or inhibition significantly inhibited $\mathrm{Kras}^{\mathrm{G} 12 \mathrm{D}}$-driven LAC [212]. Moreover, ADAM17 is shown to be required for the proteolysis of Notch1 receptor, which enhances EGFR expression and EGFR-dependent activation of ERK but not AKT in NSCLC cell lines in vitro [187].

\subsection{3. sIL-6R-Mediated IL-6 Trans-Signaling}

Previous studies have mainly focused on EGFR family ligands and the Notch receptor as downstream processed substrates of ADAM17. Given that ADAM17 sheds over 70 substrates, there lies the need to investigate the potential role of other ADAM17 substrates in cancer. In this respect, IL-6 trans-signaling via sIL-6R has recently emerged as a central driver of Kras mutant LAC and CRC, the latter via EGFR signaling which paves the way to potentially exploit components of the IL-6 trans-signaling axis (including ADAM17) as therapeutic targets in patients who develop resistance to EGFR blockade [29,97,132,197].

Classical IL-6 signaling requires the binding of IL-6 to the IL-6R complex, which consists of the transmembrane proteins gp130 and IL-6R [213]. IL-6 classical signaling is thought to mediate the protective immune responses of IL-6 during host defense, homeostasis and tissue regeneration in steady-state conditions [213]. In contrast, IL-6 trans-signaling takes place when the soluble form of IL-6R binds to IL-6, following which, the IL-6/sIL-6R complex acts as an agonist by binding to the ubiquitously expressed gp130 (Figure 9). This confers IL-6 responsiveness to cells that do not express the IL-6R and augments the spectrum of effects of classical IL-6 signaling in cells expressing IL-6R [138,213,214]. IL-6 trans-signaling has been implicated in the pathogenesis of numerous inflammatory conditions and malignancies, the latter including those to which ADAM17 has also been associated with, namely CRC, pancreatic cancer and lung cancer [29,97,213-217].

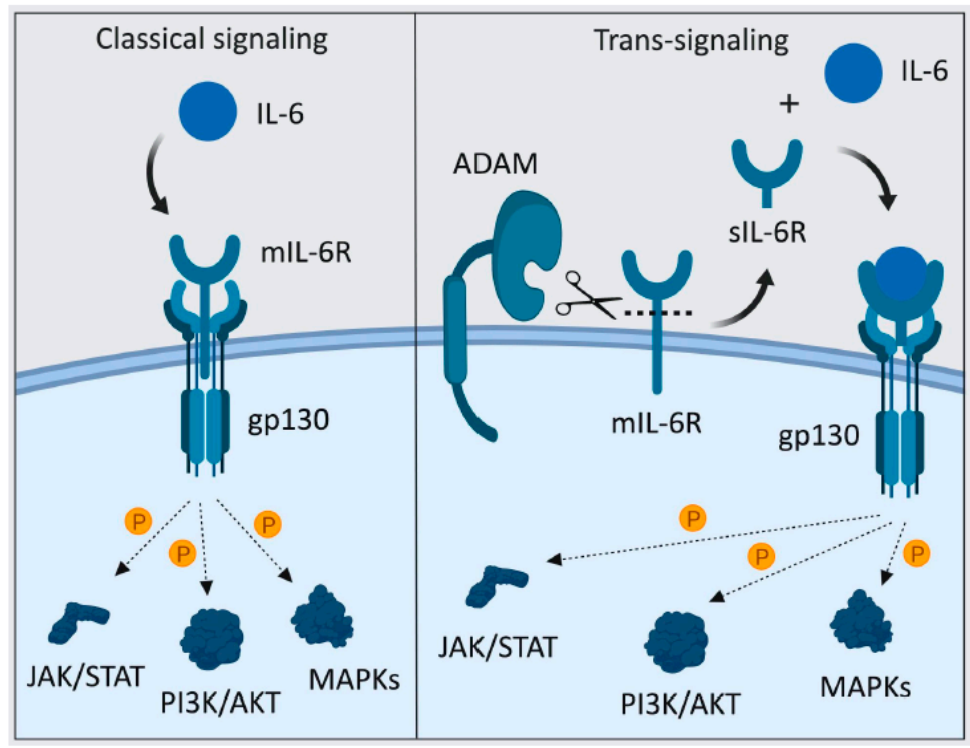

Figure 9. Classical IL-6 signaling via membrane-bound (m) IL-6R, and trans-signaling via soluble (s) IL-6R. Left panel: For classical signaling, upon IL-6 binding to its membrane-bound (m) IL-6R, a complex is formed with the signal-transducing gp130 co-receptor to elicit intracellular signaling via numerous signaling cascades. Right panel: For trans-signaling, ADAM proteases (e.g., ADAM17) cleave mIL-6R to release soluble (s) IL-6R, which then binds to free IL-6 to form a signal-transducing receptor complex with gp130. Since gp130 is ubiquitously expressed, IL-6 trans-signaling can both amplify the signal output on mIL-6R-expressing cells, as well as elicit IL-6 signaling in cells not expressing mIL-6R. 
Regarding lung cancer, blocking of IL-6 trans-signaling using sgp $130 \mathrm{Fc}-$ which is a fusion protein of sgp130 and the crystallizable fragment of immunoglobulin G1—or the anti-IL-6R monoclonal antibodies $1 \mathrm{~F} 7$ and $25 \mathrm{~F} 10$, ameliorated tumourigenesis in the oncogenic $\mathrm{Kras}^{\mathrm{G} 12 \mathrm{D}}$-induced LAC mouse model $[29,97,218]$. Furthermore, in an LAC-associated cachexia mouse model driven by oncogenic Kras, IL-6 trans-signaling, via modulating STAT3, has been shown to promote muscle wasting [197].

ADAM17 and ADAM10 are the main sheddases of human and murine sIL-6R. While ADAM17 releases sIL-6R in an induced manner, ADAM10 is responsible for the constitutive release of sIL-6R, which can be compensated for by ADAM17 [219]. Notably, the predominant role of ADAM17 in mediating the pathological consequences of deregulated sIL-6R-driven IL-6 trans-signaling has recently been reported in Kras mutant LAC and cigarette smoke carcinogen (NNK)-induced lung cancer [29,131]. In this regard, ADAM17 is overactivated via p38 MAPK-mediated threonine phosphorylation, following which, activated ADAM17 drives the preferential processing of the sIL-6R, which induces lung cancer cell proliferation through ERK1/2 MAPK activation. Moreover, inhibition of ADAM17 using genetic and prodomain inhibitor approaches significantly impaired tumour growth in LAC models and xenografts $[29,131]$. Interestingly, the protection against LAC formation in the Kras ${ }^{\mathrm{G} 12 \mathrm{D}}$ model was greater upon blockade of ADAM17 versus IL-6 trans-signaling, which raises the tantalizing prospect that ADAM17 may also employ additional processes substrates, albeit in a minor role, to promote oncogenic Kras-driven LAC [29,97].

\section{Conclusions and Future Remarks}

In summary, the therapeutic targeting of ADAM17 represents an attractive strategy to tackle LAC and other conditions of the lung (e.g., asthma, emphysema), and for that matter, other cancers (e.g., CRC and pancreatic cancer) with aberrant ADAM17 activity and/or expression. Moreover, ADAM17 inhibition may serve as a new indirect avenue to target the oncogenic activities of mutant KRAS in cancers including lung cancer (i.e., LAC), CRC and pancreatic cancer. In the context of lung cancer, it will be of interest to assess the driver role of ADAM17 in other lung cancer subtypes (e.g., KRAS wild-type LAC, EGFR mutant LAC, squamous cell carcinoma). Furthermore, in light of the preferential requirement by ADAM17 for the IL-6R substrate to facilitate its pro-tumourigenic actions in KRAS mutant LAC, the prospect of targeting ADAM17 versus sIL-6R-dependent IL-6 trans-signaling in LAC is worth considering. Current strategies to target IL-6 in the clinic have relied upon antibody-mediated approaches against IL- 6 or IL-6R that block both pathological trans-signaling and homeostatic (i.e., protective) classical signaling [213]. However, a major drawback with such antibody therapies in the clinic, such as tocilizumab and sarilumab, is that they invariably cause side effects comprising infections due to an impaired host defence against bacteria, imbalanced metabolism leading to higher blood cholesterol levels, and perforated lesions in the gastrointestinal tract $[213,220]$. Since the therapeutic targeting of ADAM17-with a highly specific and non-toxic prodomain inhibitor-in the preclinical $\mathrm{Kras}^{\mathrm{G} 12 \mathrm{D}}$ LAC model displayed enhanced anti-tumour activity compared to anti-IL-6R antibodies [32,100], the use of ADAM17 inhibitors to specifically block pathological IL-6 trans-signaling in the lung promises to be a more effective and safer strategy to ameliorate disease states, including KRAS mutant LAC, driven by IL-6 trans-signaling. In this regard, the identification of sIL-6R as a key molecular read-out for ADAM17 activity in LAC has potential for clinical translation, whereby sIL-6R could be exploited as a surrogate biomarker (i.e., released into the blood of patients for detection by ELISA) for ADAM17 activity to assist in the stratification of LAC patients predicted to respond to anti-ADAM17 therapies. Despite the promise of targeting the ADAM17-sIL-6R axis in LAC, we do nonetheless acknowledge the possible involvement, albeit minor, of additional ADAM17 substrates (among the $>70$ known) in LAC. Accordingly, future work is warranted to investigate the full substrate repertoire of ADAM17 in LAC, for instance, using mass-spectrometric-based proteomic analyses, including the terminal amine isotopic labelling of substrates (TAILS) method, to identify new drug targets and biomarkers, and to reveal the role of ADAM17 in other disease modalities. 
Author Contributions: M.I.S. and B.J.J. wrote and edited the manuscript, and S.R.-J. edited the manuscript.

Funding: The work of B.J.J. was supported by research grants from the National Health and Medical Research Council (NHMRC) of Australia, the United States Department of Defense (Lung Cancer Research Program Idea Development Award), as well as the Operational Infrastructure Support Program by the Victorian Government of Australia. The work of S.R.-J. is supported by grants from the Deutsche Forschungsgemeinschaft, Bonn, Germany (SFB877 project A1) and by the Cluster of Excellence 'Inflammation at Interfaces'. M.I.S. is supported by a Monash International Postgraduate Research Scholarship and a Monash Postgraduate Publication Award, and B.J.J. is supported by an NHMRC Senior Medical Research Fellowship.

Conflicts of Interest: The authors declare no conflict of interest.

\section{References}

1. Torre, L.A.; Siegel, R.L.; Jemal, A. Lung cancer statistics. Adv Exp Med Biol. 2016, 893, 1-19. [PubMed]

2. Torre, L.A.; Siegel, R.L.; Ward, E.M.; Jemal, A. Global Cancer Incidence and Mortality Rates and Trends-An Update. Cancer Epidemiol. Biomarkers Prev. 2016, 25, 16-27. [CrossRef] [PubMed]

3. Cheung, W.; Nguyen, D. Lineage factors and differentiation states in lung cancer progression. Oncogene 2015, 34, 5771. [CrossRef] [PubMed]

4. Zappa, C.; Mousa, S.A. Non-small cell lung cancer: Current treatment and future advances. Transl. Lung Cancer Res. 2016, 5, 288. [CrossRef] [PubMed]

5. Tan, W.-L.; Jain, A.; Takano, A.; Newell, E.W.; Iyer, N.G.; Lim, W.-T.; Tan, E.-H.; Zhai, W.; Hillmer, A.M.; Tam, W.-L. Novel therapeutic targets on the horizon for lung cancer. Lancet Oncol. 2016, 17, e347-e362. [CrossRef]

6. Chen, Z.; Fillmore, C.M.; Hammerman, P.S.; Kim, C.F.; Wong, K.-K. Non-small-cell lung cancers: A heterogeneous set of diseases. Nat. Rev. Cancer 2014, 14, 535. [CrossRef] [PubMed]

7. Stephen, A.G.; Esposito, D.; Bagni, R.K.; McCormick, F. Dragging ras back in the ring. Cancer Cell 2014, 25, 272-281. [CrossRef]

8. Santos, E.; Martin-Zanca, D.; Reddy, E.P.; Pierotti, M.A.; Della Porta, G.; Barbacid, M. Malignant activation of a K-ras oncogene in lung carcinoma but not in normal tissue of the same patient. Science 1984, 223, 661-664. [CrossRef]

9. Network, C.G.A.R. Comprehensive molecular profiling of lung adenocarcinoma. Nature 2014, $511,543$.

10. Fisher, G.H.; Wellen, S.L.; Klimstra, D.; Lenczowski, J.M.; Tichelaar, J.W.; Lizak, M.J.; Whitsett, J.A.; Koretsky, A.; Varmus, H.E. Induction and apoptotic regression of lung adenocarcinomas by regulation of a K-Ras transgene in the presence and absence of tumor suppressor genes. Genes Dev. 2001, 15, 3249-3262. [CrossRef]

11. Ahrendt, S.A.; Decker, P.A.; Alawi, E.A.; Zhu, Y.r.; Sanchez-Cespedes, M.; Yang, S.C.; Haasler, G.B.; Kajdacsy-Balla, A.; Demeure, M.J.; Sidransky, D. Cigarette smoking is strongly associated with mutation of the K-ras gene in patients with primary adenocarcinoma of the lung. Cancer 2001, 92, 1525-1530. [CrossRef]

12. Liao, J.; Shima, F.; Araki, M.; Ye, M.; Muraoka, S.; Sugimoto, T.; Kawamura, M.; Yamamoto, N.; Tamura, A.; Kataoka, T. Two conformational states of Ras GTPase exhibit differential GTP-binding kinetics. Biochem. Biophys. Res. Commun. 2008, 369, 327-332. [CrossRef] [PubMed]

13. Gysin, S.; Salt, M.; Young, A.; McCormick, F. Therapeutic strategies for targeting ras proteins. Genes Cancer 2011, 2, 359-372. [CrossRef] [PubMed]

14. Karachaliou, N.; Mayo, C.; Costa, C.; Magri, I.; Gimenez-Capitan, A.; Molina-Vila, M.A.; Rosell, R. KRAS mutations in lung cancer. Clin. Lung Cancer 2013, 14, 205-214. [CrossRef] [PubMed]

15. Ying, H.; Kimmelman, A.C.; Lyssiotis, C.A.; Hua, S.; Chu, G.C.; Fletcher-Sananikone, E.; Locasale, J.W.; Son, J.; Zhang, H.; Coloff, J.L. Oncogenic Kras maintains pancreatic tumors through regulation of anabolic glucose metabolism. Cell 2012, 149, 656-670. [CrossRef] [PubMed]

16. Gwinn, D.M.; Lee, A.G.; Briones-Martin-del-Campo, M.; Conn, C.S.; Simpson, D.R.; Scott, A.I.; Le, A.; Cowan, T.M.; Ruggero, D.; Sweet-Cordero, E.A. Oncogenic KRAS regulates amino acid homeostasis and asparagine biosynthesis via ATF4 and alters sensitivity to L-asparaginase. Cancer Cell 2018, 33, 91-107. [CrossRef] [PubMed]

17. Yuan, T.L.; Amzallag, A.; Bagni, R.; Yi, M.; Afghani, S.; Burgan, W.; Fer, N.; Strathern, L.A.; Powell, K.; Smith, B. Differential effector engagement by oncogenic KRAS. Cell Rep. 2018, 22, 1889-1902. [CrossRef] [PubMed] 
18. Ostrem, J.M.; Shokat, K.M. Direct small-molecule inhibitors of KRAS: From structural insights to mechanism-based design. Nat. Rev. Drug Discov. 2016, 15, 771. [CrossRef] [PubMed]

19. Ambrogio, C.; Köhler, J.; Zhou, Z.-W.; Wang, H.; Paranal, R.; Li, J.; Capelletti, M.; Caffarra, C.; Li, S.; Lv, Q. KRAS dimerization impacts MEK inhibitor sensitivity and oncogenic activity of mutant KRAS. Cell 2018, 172, 857-868. [CrossRef] [PubMed]

20. Welsch, M.E.; Kaplan, A.; Chambers, J.M.; Stokes, M.E.; Bos, P.H.; Zask, A.; Zhang, Y.; Sanchez-Martin, M.; Badgley, M.A.; Huang, C.S. Multivalent small-molecule pan-RAS inhibitors. Cell 2017, 168, 878-889. [CrossRef] [PubMed]

21. Tan, G.; Wang, Z.; Zhang, X.; Cai, Z.; Zhang, J. Induction of CTLs by DCs pulsed with K-ras mutant peptide on the surface of nanoparticles in the treatment of pancreatic cancer. Oncol. Rep. 2011, 26, 215-221. [PubMed]

22. Weng, T.; Yen, M.; Huang, C.; Hung, J.-J.; Chen, Y.; Chen, W.; Wang, C.; Chang, J.-Y.; Lai, M.-D. DNA vaccine elicits an efficient antitumor response by targeting the mutant Kras in a transgenic mouse lung cancer model. Gene Ther. 2014, 21, 888. [CrossRef] [PubMed]

23. Wedén, S.; Klemp, M.; Gladhaug, I.P.; Møller, M.; Eriksen, J.A.; Gaudernack, G.; Buanes, T. Long-term follow-up of patients with resected pancreatic cancer following vaccination against mutant K-ras. Int. J. Cancer 2011, 128, 1120-1128. [CrossRef] [PubMed]

24. Wang, Q.J.; Yu, Z.; Griffith, K.; Hanada, K.-i.; Restifo, N.P.; Yang, J.C. Identification of T-cell receptors targeting KRAS-mutated human tumors. Cancer Immunol. Res. 2016, 4, 204-214. [CrossRef]

25. Kohler, J.; Catalano, M.; Ambrogio, C. Back to the bench? MEK and ERK inhibitors for the treatment of KRAS mutant lung adenocarcinoma. Curr. Med. Chem. 2018, 25, 558-574. [CrossRef]

26. Fedele, C.; Ran, H.; Diskin, B.; Wei, W.; Jen, J.; Geer, M.J.; Araki, K.; Ozerdem, U.; Simeone, D.M.; Miller, G. SHP2 inhibition prevents adaptive resistance to MEK inhibitors in multiple cancer models. Cancer Discov. 2018, 8, 1237-1249. [CrossRef]

27. Mainardi, S.; Mulero-Sánchez, A.; Prahallad, A.; Germano, G.; Bosma, A.; Krimpenfort, P.; Lieftink, C.; Steinberg, J.D.; De Wit, N.; Gonçalves-Ribeiro, S. SHP2 is required for growth of KRAS-mutant non-small-cell lung cancer in vivo. Nat. Med. 2018, 24, 961. [CrossRef]

28. Lu, H.; Liu, C.; Velazquez, R.; Wang, H.; Dunkl, L.M.; Kazic-Legueux, M.; Haberkorn, A.; Billy, E.; Manchado, E.; Brachmann, S.M. SHP2 inhibition overcomes RTK-mediated pathway re-activation in KRAS mutant tumors treated with MEK inhibitors. Mol. Cancer Ther. 2019. [CrossRef]

29. Saad, M.I.; Alhayyani, S.; McLeod, L.; Yu, L.; Alanazi, M.; Deswaerte, V.; Tang, K.; Jarde, T.; Smith, J.A.; Prodanovic, Z.; et al. ADAM17 selectively activates the IL-6 trans-signaling/ERK MAPK axis in KRAS-addicted lung cancer. EMBO Mol. Med. 2019, 11, 4. [CrossRef]

30. Burgess, A.W. EGFR family: Structure physiology signalling and therapeutic targets. Growth Factors 2008, 26, 263-274. [CrossRef]

31. Wheeler, D.L.; Dunn, E.F.; Harari, P.M. Understanding resistance to EGFR inhibitors-impact on future treatment strategies. Nat. Rev. Clin. Oncol. 2010, 7, 493. [CrossRef] [PubMed]

32. Cho, H.-S.; Mason, K.; Ramyar, K.X.; Stanley, A.M.; Gabelli, S.B.; Denney Jr, D.W.; Leahy, D.J. Structure of the extracellular region of HER2 alone and in complex with the Herceptin Fab. Nature 2003, 421, 756. [CrossRef] [PubMed]

33. Schlessinger, J. Receptor tyrosine kinases: Legacy of the first two decades. Cold Spring Harb. Perspect. Biol. 2014, 6, a008912. [CrossRef] [PubMed]

34. Cho, H.-S.; Leahy, D.J. Structure of the extracellular region of HER3 reveals an interdomain tether. Science 2002, 297, 1330-1333. [CrossRef]

35. Carpenter, G. ErbB-4: Mechanism of action and biology. Exp Cell Res. 2003, 284, 66-77. [CrossRef]

36. Grandis, J.R.; Melhem, M.F.; Gooding, W.E.; Day, R.; Holst, V.A.; Wagener, M.M.; Drenning, S.D.; Tweardy, D.J. Levels of TGF- $\alpha$ and EGFR protein in head and neck squamous cell carcinoma and patient survival. J. Natl. Cancer Inst. 1998, 90, 824-832. [CrossRef]

37. Lee, J.W.; Soung, Y.H.; Kim, S.Y.; Nam, H.K.; Park, W.S.; Nam, S.W.; Kim, M.S.; Sun, D.I.; Lee, Y.S.; Jang, J.J. Somatic mutations of EGFR gene in squamous cell carcinoma of the head and neck. Clin. Cancer Res. 2005, 11, 2879-2882. [CrossRef]

38. Rusch, V.; Baselga, J.; Cordon-Cardo, C.; Orazem, J.; Zaman, M.; Hoda, S.; McIntosh, J.; Kurie, J.; Dmitrovsky, E. Differential expression of the epidermal growth factor receptor and its ligands in primary non-small cell lung cancers and adjacent benign lung. Cancer Res. 1993, 53, 2379-2385. 
39. Lynch, T.J.; Bell, D.W.; Sordella, R.; Gurubhagavatula, S.; Okimoto, R.A.; Brannigan, B.W.; Harris, P.L.; Haserlat, S.M.; Supko, J.G.; Haluska, F.G. Activating mutations in the epidermal growth factor receptor underlying responsiveness of non-small-cell lung cancer to gefitinib. N. Engl. J. Med. 2004, 350, 2129-2139. [CrossRef]

40. Spano, J.-P.; Lagorce, C.; Atlan, D.; Milano, G.; Domont, J.; Benamouzig, R.; Attar, A.; Benichou, J.; Martin, A.; Morere, J.-F. Impact of EGFR expression on colorectal cancer patient prognosis and survival. Ann. Oncol. 2005, 16, 102-108. [CrossRef]

41. Barber, T.D.; Vogelstein, B.; Kinzler, K.W.; Velculescu, V.E. Somatic mutations of EGFR in colorectal cancers and glioblastomas. N. Engl. J. Med. 2004, 351, 2883. [CrossRef] [PubMed]

42. Bhargava, R.; Gerald, W.L.; Li, A.R.; Pan, Q.; Lal, P.; Ladanyi, M.; Chen, B. EGFR gene amplification in breast cancer: Correlation with epidermal growth factor receptor mRNA and protein expression and HER-2 status and absence of EGFR-activating mutations. Mod. Pathol. 2005, 18, 1027. [CrossRef] [PubMed]

43. Ardito, C.M.; Grüner, B.M.; Takeuchi, K.K.; Lubeseder-Martellato, C.; Teichmann, N.; Mazur, P.K.; DelGiorno, K.E.; Carpenter, E.S.; Halbrook, C.J.; Hall, J.C. EGF receptor is required for KRAS-induced pancreatic tumorigenesis. Cancer Cell 2012, 22, 304-317. [CrossRef]

44. Sheng, Q.; Liu, J. The therapeutic potential of targeting the EGFR family in epithelial ovarian cancer. Br. J. Cancer 2011, 104, 1241. [CrossRef] [PubMed]

45. Terashima, M.; Kitada, K.; Ochiai, A.; Ichikawa, W.; Kurahashi, I.; Sakuramoto, S.; Katai, H.; Sano, T.; Imamura, H.; Sasako, M. Impact of expression of human epidermal growth factor receptors EGFR and ERBB2 on survival in stage II/III gastric cancer. Clin. Cancer Res. 2012, 18, 5992-6000. [CrossRef] [PubMed]

46. Heimberger, A.B.; Learn, C.A.; Archer, G.E.; McLendon, R.E.; Chewning, T.A.; Tuck, F.L.; Pracyk, J.B.; Friedman, A.H.; Friedman, H.S.; Bigner, D.D. Brain tumors in mice are susceptible to blockade of epidermal growth factor receptor (EGFR) with the oral, specific, EGFR-tyrosine kinase inhibitor ZD1839 (iressa). Clin. Cancer Res. 2002, 8, 3496-3502. [PubMed]

47. Mellinghoff, I.K.; Wang, M.Y.; Vivanco, I.; Haas-Kogan, D.A.; Zhu, S.; Dia, E.Q.; Lu, K.V.; Yoshimoto, K.; Huang, J.H.; Chute, D.J. Molecular determinants of the response of glioblastomas to EGFR kinase inhibitors. N. Engl. J. Med. 2005, 353, 2012-2024. [CrossRef]

48. Husgafvel-Pursiainen, K.; Hackman, P.; Ridanpää, M.; Anttila, S.; Karjalainen, A.; Partanen, T.; Taikina-Aho, O.; Heikkilä, L.; Vainio, H. K-ras mutations in human adenocarcinoma of the lung: Association with smoking and occupational exposure to asbestos. Int. J. Cancer 1993, 53, 250-256. [CrossRef] [PubMed]

49. Ward, W.H.; Cook, P.N.; Slater, A.M.; Davies, D.H.; Holdgate, G.A. Epidermal growth factor receptor tyrosine kinase: Investigation of catalytic mechanism, structure-based searching and discovery of a potent inhibitor. Biochem. Pharmacol. 1994, 48, 659-666. [CrossRef]

50. Wakeling, A.E.; Guy, S.P.; Woodburn, J.R.; Ashton, S.E.; Curry, B.J.; Barker, A.J.; Gibson, K.H. ZD1839 (Iressa): An orally active inhibitor of epidermal growth factor signaling with potential for cancer therapy. Cancer Res. 2002, 62, 5749-5754.

51. Paez, J.G.; Jänne, P.A.; Lee, J.C.; Tracy, S.; Greulich, H.; Gabriel, S.; Herman, P.; Kaye, F.J.; Lindeman, N.; Boggon, T.J. EGFR mutations in lung cancer: Correlation with clinical response to gefitinib therapy. Science 2004, 304, 1497-1500. [CrossRef] [PubMed]

52. Pao, W.; Miller, V.; Zakowski, M.; Doherty, J.; Politi, K.; Sarkaria, I.; Singh, B.; Heelan, R.; Rusch, V.; Fulton, L. EGF receptor gene mutations are common in lung cancers from "never smokers" and are associated with sensitivity of tumors to gefitinib and erlotinib. Proc. Natl. Acad. Sci. USA 2004, 101, 13306-13311. [CrossRef] [PubMed]

53. Sordella, R.; Bell, D.W.; Haber, D.A.; Settleman, J. Gefitinib-sensitizing EGFR mutations in lung cancer activate anti-apoptotic pathways. Science 2004, 305, 1163-1167. [CrossRef]

54. Goldstein, N.I.; Prewett, M.; Zuklys, K.; Rockwell, P.; Mendelsohn, J. Biological efficacy of a chimeric antibody to the epidermal growth factor receptor in a human tumor xenograft model. Clin. Cancer Res. 1995, 1, 1311-1318. [PubMed]

55. Van Cutsem, E.; Köhne, C.-H.; Hitre, E.; Zaluski, J.; Chang Chien, C.-R.; Makhson, A.; D’haens, G.; Pintér, T.; Lim, R.; Bodoky, G. Cetuximab and chemotherapy as initial treatment for metastatic colorectal cancer. $N$. Engl. J. Med. 2009, 360, 1408-1417. [CrossRef] [PubMed] 
56. Vermorken, J.B.; Mesia, R.; Rivera, F.; Remenar, E.; Kawecki, A.; Rottey, S.; Erfan, J.; Zabolotnyy, D.; Kienzer, H.-R.; Cupissol, D. Platinum-based chemotherapy plus cetuximab in head and neck cancer. N. Engl. J. Med. 2008, 359, 1116-1127. [CrossRef] [PubMed]

57. Yang, X.-D.; Jia, X.-C.; Corvalan, J.R.; Wang, P.; Davis, C.G. Development of ABX-EGF, a fully human anti-EGF receptor monoclonal antibody, for cancer therapy. Crit. Rev. Oncol. Hematol. 2001, 38, 17-23. [CrossRef]

58. Giusti, R.M.; Shastri, K.; Pilaro, A.M.; Fuchs, C.; Cordoba-Rodriguez, R.; Koti, K.; Rothmann, M.; Men, A.Y.; Zhao, H.; Hughes, M. US Food and Drug Administration approval: Panitumumab for epidermal growth factor receptor-expressing metastatic colorectal carcinoma with progression following fluoropyrimidine-, oxaliplatin-, and irinotecan-containing chemotherapy regimens. Clin. Cancer Res. 2008, 14, 1296-1302. [CrossRef]

59. Kris, M.G.; Natale, R.B.; Herbst, R.S.; Lynch Jr, T.J.; Prager, D.; Belani, C.P.; Schiller, J.H.; Kelly, K.; Spiridonidis, H.; Sandler, A. Efficacy of gefitinib, an inhibitor of the epidermal growth factor receptor tyrosine kinase, in symptomatic patients with non-small cell lung cancer: A randomized trial. JAMA 2003, 290, 2149-2158. [CrossRef]

60. Geyer, C.E.; Forster, J.; Lindquist, D.; Chan, S.; Romieu, C.G.; Pienkowski, T.; Jagiello-Gruszfeld, A.; Crown, J.; Chan, A.; Kaufman, B. Lapatinib plus capecitabine for HER2-positive advanced breast cancer. N. Engl. J. Med. 2006, 355, 2733-2743. [CrossRef]

61. Campiglio, M.; Locatelli, A.; Olgiati, C.; Normanno, N.; Somenzi, G.; Viganò, L.; Fumagalli, M.; Ménard, S.; Gianni, L. Inhibition of proliferation and induction of apoptosis in breast cancer cells by the epidermal growth factor receptor (EGFR) tyrosine kinase inhibitor ZD1839 ('Iressa') is independent of EGFR expression level. J. Cell. Physiol. 2004, 198, 259-268. [CrossRef] [PubMed]

62. Sellmann, L.; Fenchel, K.; Dempke, W.C. Improved overall survival following tyrosine kinase inhibitor treatment in advanced or metastatic non-small-cell lung cancer-the Holy Grail in cancer treatment? Transl. Lung Cancer Res. 2015, 4, 223. [PubMed]

63. Giaccone, G.; Herbst, R.S.; Manegold, C.; Scagliotti, G.; Rosell, R.; Miller, V.; Natale, R.B.; Schiller, J.H.; von Pawel, J.; Pluzanska, A. Gefitinib in combination with gemcitabine and cisplatin in advanced non-small-cell lung cancer: A phase III trial-INTACT 1. J. Clin. Oncol. 2004, 22, 777-784. [CrossRef] [PubMed]

64. Celli, B.R. Chronic obstructive pulmonary disease and lung cancer: Common pathogenesis, shared clinical challenges. Proc. Am. Thorac. Soc. 2012, 9, 74-79. [CrossRef] [PubMed]

65. Hecht, S.S. Cigarette smoking: Cancer risks, carcinogens, and mechanisms. Langenbecks Arch. Surg. 2006, 391, 603-613. [CrossRef] [PubMed]

66. Akopyan, G.; Bonavida, B. Understanding tobacco smoke carcinogen NNK and lung tumorigenesis. Int. J. Oncol. 2006, 29, 745-752. [CrossRef]

67. Hecht, S.; Hoffmann, D. N-nitroso compounds and tobacco-induced cancers in man. IARC Sci. Publ. 1990, $105,54-61$.

68. Hecht, S.S. Research opportunities related to establishing standards for tobacco products under the Family Smoking Prevention and Tobacco Control Act. Nicotine Tob. Res. 2011, 14, 18-28. [CrossRef]

69. Thomas, J.L.; Hecht, S.S.; Luo, X.; Ming, X.; Ahluwalia, J.S.; Carmella, S.G. Thirdhand tobacco smoke: A tobacco-specific lung carcinogen on surfaces in smokers' homes. Nicotine Tob. Res. 2013, 16, 26-32. [CrossRef]

70. Rivenson, A.; Hoffmann, D.; Prokopczyk, B.; Amin, S.; Hecht, S.S. Induction of lung and exocrine pancreas tumors in F344 rats by tobacco-specific and Areca-derived N-nitrosamines. Cancer Res. 1988, 48, 6912-6917.

71. Hecht, S.S.; Adams, J.D.; Numoto, S.; Hoffmann, D. Induction of respiratory tract tumors in Syrian golden hamsters by a single dose of 4-(methylnitrosamino)-1-(3-pyridyl)-1-butanone (NNK) and the effect of smoke inhalation. Carcinogenesis 1983, 4, 1287-1290. [CrossRef] [PubMed]

72. Castonguay, A.; Lin, D.; Stoner, G.D.; Radok, P.; Furuya, K.; Hecht, S.S.; Schut, H.A.; Klaunig, J.E. Comparative carcinogenicity in A/J mice and metabolism by cultured mouse peripheral lung of $\mathrm{N}^{\prime}$-nitrosonornicotine, 4-(methylnitrosamino)-1-(3-pyridyl)-1-butanone, and their analogues. Cancer Res. 1983, 43, 1223-1229. [PubMed]

73. Belinsky, S.A.; Devereux, T.R.; Foley, J.F.; Maronpot, R.R.; Anderson, M.W. Role of the Alveor Type II Cell in the Development and Progression of Pulmonary Tumors Induced bt 4-(Methylnitrosamino)-(3-pyridyl)-1-butanone in the A/J Mouse. Cancer Res. 1992, 52, 3164-3173. [PubMed] 
74. Fujimoto, J.; Kadara, H.; Men, T.; van Pelt, C.; Lotan, D.; Lotan, R. Comparative functional genomics analysis of NNK tobacco-carcinogen induced lung adenocarcinoma development in Gprc5a-knockout mice. PLoS ONE 2010, 5, e11847. [CrossRef] [PubMed]

75. Ehrhardt, A.; Bartels, T.; Klocke, R.; Paul, D.; Halter, R. Increased susceptibility to the tobacco carcinogen 4-(methylnitrosamino)-1-(3-pyridyl)-1-butanone in transgenic mice overexpressing c-myc and epidermal growth factor in alveolar type II cells. J. Cancer Res. Clin. Oncol. 2003, 129, 71-75. [PubMed]

76. Yang, Y.; Zhang, Z.; Mukherjee, A.B.; Linnoila, R.I. Increased susceptibility of mice lacking Clara cell 10-kDa protein to lung tumorigenesis by 4-(methylnitrosamino)-1-(3-pyridyl)-1-butanone, a potent carcinogen in cigarette smoke. J. Biol. Chem. 2004, 279, 29336-29340. [CrossRef]

77. Hecht, S.S. Recent studies on mechanisms of bioactivation and detoxification of 4-(methylnitrosamino)1-(3-pyridyl)-1-butanone (NNK), a tobacco-specific lung carcinogen. Crit. Rev. Toxicol. 1996, 26, 163-181. [CrossRef] [PubMed]

78. Demizu, Y.; Sasaki, R.; Trachootham, D.; Pelicano, H.; Colacino, J.A.; Liu, J.; Huang, P. Alterations of cellular redox state during NNK-induced malignant transformation and resistance to radiation. Antioxid. Redox Signal. 2008, 10, 951-961. [CrossRef]

79. Ho, Y.-S.; Chen, C.-H.; Wang, Y.-J.; Pestell, R.G.; Albanese, C.; Chen, R.-J.; Chang, M.-C.; Jeng, J.-H.; Lin, S.-Y.; Liang, Y.-C. Tobacco-specific carcinogen 4-(methylnitrosamino)-1-(3-pyridyl)-1-butanone (NNK) induces cell proliferation in normal human bronchial epithelial cells through $\mathrm{NF} \kappa \mathrm{B}$ activation and cyclin D1 up-regulation. Toxicol. Appl. Pharmacol. 2005, 205, 133-148. [CrossRef]

80. Jin, Z.; Gao, F.; Flagg, T.; Deng, X. Tobacco-specific nitrosamine 4-(methylnitrosamino)-1-(3-pyridyl)-1butanone promotes functional cooperation of $\mathrm{Bcl} 2$ and c-Myc through phosphorylation in regulating cell survival and proliferation. J. Biol. Chem. 2004, 279, 40209-40219. [CrossRef]

81. Jin, Z.; May, W.S.; Gao, F.; Flagg, T.; Deng, X. Bcl2 suppresses DNA repair by enhancing c-Myc transcriptional activity. J. Biol. Chem. 2006, 281, 14446-14456. [CrossRef] [PubMed]

82. Jull, B.; Plummer, H.; Schuller, H. Nicotinic receptor-mediated activation by the tobacco-specific nitrosamine NNK of a Raf-1/MAP kinase pathway, resulting in phosphorylation of c-myc in human small cell lung carcinoma cells and pulmonary neuroendocrine cells. J. Cancer Res. Clin. Oncol. 2001, 127,707-717. [PubMed]

83. Miller, A.; Brooks, G.D.; Mcleod, L.; Ruwanpura, S.; Jenkins, B.J. Differential involvement of gp130 signalling pathways in modulating tobacco carcinogen-induced lung tumourigenesis. Oncogene 2015, 34, 1510. [CrossRef] [PubMed]

84. El-Bayoumy, K.; Iatropoulos, M.; Amin, S.; Hoffmann, D.; Wynder, E.L. Increased expression of cyclooxygenase- 2 in rat lung tumors induced by the tobacco-specific nitrosamine 4-(methylnitrosamino)4-(3-pyridyl)-1-butanone. Cancer Res. 1999, 59, 1400-1403. [PubMed]

85. Houghton, A.M.; Mouded, M.; Shapiro, S.D. Common origins of lung cancer and COPD. Nat. Med. 2008, 14, 1023-1024. [CrossRef] [PubMed]

86. Quail, D.F.; Joyce, J.A. Microenvironmental regulation of tumor progression and metastasis. Nat. Med. 2013, 19, 1423-1437. [CrossRef] [PubMed]

87. DuPage, M.; Cheung, A.F.; Mazumdar, C.; Winslow, M.M.; Bronson, R.; Schmidt, L.M.; Crowley, D.; Chen, J.; Jacks, T. Endogenous $\mathrm{T}$ cell responses to antigens expressed in lung adenocarcinomas delay malignant tumor progression. Cancer Cell 2011, 19, 72-85. [CrossRef]

88. Bellocq, A.; Antoine, M.; Flahault, A.; Philippe, C.; Crestani, B.; Bernaudin, J.F.; Mayaud, C.; Milleron, B.; Baud, L.; Cadranel, J. Neutrophil alveolitis in bronchioloalveolar carcinoma: Induction by tumor-derived interleukin-8 and relation to clinical outcome. Am. J. Pathol. 1998, 152, 83-92.

89. Zaynagetdinov, R.; Sherrill, T.P.; Polosukhin, V.V.; Han, W.; Ausborn, J.A.; McLoed, A.G.; McMahon, F.B.; Gleaves, L.A.; Degryse, A.L.; Stathopoulos, G.T.; et al. A critical role for macrophages in promotion of urethane-induced lung carcinogenesis. J. Immunol. 2011, 187, 5703-5711. [CrossRef]

90. Vignaud, J.-M.; Marie, B.; Klein, N.; Plénat, F.; Pech, M.; Borrelly, J.; Martinet, N.; Duprez, A.; Martinet, Y. The role of platelet-derived growth factor production by tumor-associated macrophages in tumor stroma formation in lung cancer. Cancer Res. 1994, 54, 5455-5463.

91. Ji, H.; Houghton, A.; Mariani, T.; Perera, S.; Kim, C.; Padera, R.; Tonon, G.; McNamara, K.; Marconcini, L.; Hezel, A. K-ras activation generates an inflammatory response in lung tumors. Oncogene 2006, 25, $2105-2112$. [CrossRef] [PubMed] 
92. Chang, S.H.; Mirabolfathinejad, S.G.; Katta, H.; Cumpian, A.M.; Gong, L.; Caetano, M.S.; Moghaddam, S.J.; Dong, C. T helper 17 cells play a critical pathogenic role in lung cancer. Proc. Natl. Acad. Sci. USA 2014, 111, 5664-5669. [CrossRef] [PubMed]

93. Jin, C.; Lagoudas, G.K.; Zhao, C.; Bullman, S.; Bhutkar, A.; Hu, B.; Ameh, S.; Sandel, D.; Liang, X.S.; Mazzilli, S. Commensal Microbiota Promote Lung Cancer Development via $\gamma \delta$ T Cells. Cell 2019, 5, 998-1013. [CrossRef] [PubMed]

94. Numasaki, M.; Watanabe, M.; Suzuki, T.; Takahashi, H.; Nakamura, A.; McAllister, F.; Hishinuma, T.; Goto, J.; Lotze, M.T.; Kolls, J.K. IL-17 enhances the net angiogenic activity and in vivo growth of human non-small cell lung cancer in SCID mice through promoting CXCR-2-dependent angiogenesis. J. Immunol. 2005, 175, 6177-6189. [CrossRef] [PubMed]

95. Ancrile, B.; Lim, K.-H.; Counter, C.M. Oncogenic Ras-induced secretion of IL6 is required for tumorigenesis. Genes Dev. 2007, 21, 1714-1719. [CrossRef] [PubMed]

96. Gao, S.P.; Mark, K.G.; Leslie, K.; Pao, W.; Motoi, N.; Gerald, W.L.; Travis, W.D.; Bornmann, W.; Veach, D.; Clarkson, B. Mutations in the EGFR kinase domain mediate STAT3 activation via IL-6 production in human lung adenocarcinomas. J. Clin. Invest. 2007, 117, 3846-3856. [CrossRef]

97. Brooks, G.D.; McLeod, L.; Alhayyani, S.; Miller, A.; Russell, P.A.; Ferlin, W.; Rose-John, S.; Ruwanpura, S.; Jenkins, B.J. IL6 Trans-signaling Promotes KRAS-Driven Lung Carcinogenesis. Cancer Res. 2016, 76, 866-876. [CrossRef]

98. Chen, J.J.; Yao, P.-L.; Yuan, A.; Hong, T.-M.; Shun, C.-T.; Kuo, M.-L.; Lee, Y.-C.; Yang, P.-C. Up-regulation of tumor interleukin-8 expression by infiltrating macrophages: Its correlation with tumor angiogenesis and patient survival in non-small cell lung cancer. Clin. Cancer Res. 2003, 9, 729-737.

99. White, E.S.; Flaherty, K.R.; Carskadon, S.; Brant, A.; Iannettoni, M.D.; Yee, J.; Orringer, M.B.; Arenberg, D.A. Macrophage migration inhibitory factor and CXC chemokine expression in non-small cell lung cancer: Role in angiogenesis and prognosis. Clin. Cancer Res. 2003, 9, 853-860.

100. Yatsunami, J.; Tsuruta, N.; Ogata, K.; Wakamatsu, K.; Takayama, K.; Kawasaki, M.; Nakanishi, Y.; Hara, N.; Hayashi, S.-i. Interleukin-8 participates in angiogenesis in non-small cell, but not small cell carcinoma of the lung. Cancer Lett. 1997, 120, 101-108. [CrossRef]

101. Arenberg, D.A.; Kunkel, S.L.; Polverini, P.J.; Glass, M.; Burdick, M.D.; Strieter, R.M. Inhibition of interleukin-8 reduces tumorigenesis of human non-small cell lung cancer in SCID mice. J. Clin. Invest. 1996, 97, 2792-2802. [CrossRef] [PubMed]

102. Apte, R.N.; Dotan, S.; Elkabets, M.; White, M.R.; Reich, E.; Carmi, Y.; Song, X.; Dvozkin, T.; Krelin, Y.; Voronov, E. The involvement of IL-1 in tumorigenesis, tumor invasiveness, metastasis and tumor-host interactions. Cancer Metastasis Rev. 2006, 25, 387-408. [CrossRef] [PubMed]

103. Ridker, P.M.; MacFadyen, J.G.; Thuren, T.; Everett, B.M.; Libby, P.; Glynn, R.J.; Group, C.T. Effect of interleukin-1beta inhibition with canakinumab on incident lung cancer in patients with atherosclerosis: Exploratory results from a randomised, double-blind, placebo-controlled trial. Lancet 2017, 390, 1833-1842. [CrossRef]

104. Jenkins, B.J. Potential efficacy of interleukin-1ß inhibition in lung cancer. Lancet 2017, 390, $1813-1814$. [CrossRef]

105. Keir, M.E.; Butte, M.J.; Freeman, G.J.; Sharpe, A.H. PD-1 and its ligands in tolerance and immunity. Annu. Rev. Immunol. 2008, 26, 677-704. [CrossRef] [PubMed]

106. Jia, M.; Feng, W.; Kang, S.; Zhang, Y.; Shen, J.; He, J.; Jiang, L.; Wang, W.; Guo, Z.; Peng, G. Evaluation of the efficacy and safety of anti-PD-1 and anti-PD-L1 antibody in the treatment of non-small cell lung cancer (NSCLC): A meta-analysis. J. Thorac. Dis. 2015, 7, 455. [PubMed]

107. He, J.; Hu, Y.; Hu, M.; Li, B. Development of PD-1/PD-L1 pathway in tumor immune microenvironment and treatment for non-small cell lung cancer. Sci. Rep. 2015, 5, 13110. [CrossRef] [PubMed]

108. Brahmer, J.R.; Tykodi, S.S.; Chow, L.Q.; Hwu, W.-J.; Topalian, S.L.; Hwu, P.; Drake, C.G.; Camacho, L.H.; Kauh, J.; Odunsi, K. Safety and activity of anti-PD-L1 antibody in patients with advanced cancer. N. Engl. J. Med. 2012, 366, 2455-2465. [CrossRef]

109. Topalian, S.L.; Hodi, F.S.; Brahmer, J.R.; Gettinger, S.N.; Smith, D.C.; McDermott, D.F.; Powderly, J.D.; Carvajal, R.D.; Sosman, J.A.; Atkins, M.B. Safety, activity, and immune correlates of anti-PD-1 antibody in cancer. N. Engl. J. Med. 2012, 366, 2443-2454. [CrossRef]

110. Gooz, M. ADAM-17: The enzyme that does it all. Crit. Rev. Biochem. Mol. Biol. 2010, 45, 146-169. [CrossRef] 
111. Caescu, C.I.; Jeschke, G.R.; Turk, B.E. Active-site determinants of substrate recognition by the metalloproteinases TACE and ADAM10. Biochem. J. 2009, 424, 79-88. [CrossRef] [PubMed]

112. Blobel, C.P. ADAMs: Key components in EGFR signalling and development. Nat. Rev. Mol. Cell Biol. 2005, 6, 32-43. [CrossRef] [PubMed]

113. Le Gall, S.M.; Maretzky, T.; Issuree, P.D.; Niu, X.-D.; Reiss, K.; Saftig, P.; Khokha, R.; Lundell, D.; Blobel, C.P. ADAM17 is regulated by a rapid and reversible mechanism that controls access to its catalytic site. J. Cell Sci. 2010, 123, 3913-3922. [CrossRef] [PubMed]

114. Thiel, K.W.; Carpenter, G. ErbB-4 and TNF-alpha converting enzyme localization to membrane microdomains. Biochem. Biophys. Res. Commun. 2006, 350, 629-633. [CrossRef] [PubMed]

115. Zimina, E.P.; Bruckner-Tuderman, L.; Franzke, C.W. Shedding of collagen XVII ectodomain depends on plasma membrane microenvironment. J. Biol. Chem. 2005, 280, 34019-34024. [CrossRef] [PubMed]

116. Black, R.A.; Rauch, C.T.; Kozlosky, C.J.; Peschon, J.J.; Slack, J.L.; Wolfson, M.F.; Castner, B.J.; Stocking, K.L.; Reddy, P.; Srinivasan, S. A metalloproteinase disintegrin that releases tumour-necrosis factor- $\alpha$ from cells. Nature 1997, 385, 729-733. [CrossRef] [PubMed]

117. Moss, M.L.; Jin, S.-L.C.; Milla, M.E.; Burkhart, W.; Carter, H.L.; Chen, W.-J.; Clay, W.C.; Didsbury, J.R.; Hassler, D.; Hoffman, C.R. Cloning of a disintegrin metalloproteinase that processes precursor tumour-necrosis factor- $\alpha$. Nature 1997, 385, 733-736. [CrossRef] [PubMed]

118. Grötzinger, J.; Lorenzen, I.; Düsterhöft, S. Molecular insights into the multilayered regulation of ADAM17: The role of the extracellular region. Biochim. Biophys. Acta Mol. Cell Res. 2017, 11, 2088-2095. [CrossRef] [PubMed]

119. Jackson, L.F.; Qiu, T.H.; Sunnarborg, S.W.; Chang, A.; Zhang, C.; Patterson, C.; Lee, D.C. Defective valvulogenesis in HB-EGF and TACE-null mice is associated with aberrant BMP signaling. EMBO J. 2003, 22, 2704-2716. [CrossRef]

120. Peschon, J.J.; Slack, J.L.; Reddy, P.; Stocking, K.L.; Sunnarborg, S.W.; Lee, D.C.; Russell, W.E.; Castner, B.J.; Johnson, R.S.; Fitzner, J.N. An essential role for ectodomain shedding in mammalian development. Science 1998, 282, 1281-1284. [CrossRef]

121. Sahin, U.; Weskamp, G.; Kelly, K.; Zhou, H.M.; Higashiyama, S.; Peschon, J.; Hartmann, D.; Saftig, P.; Blobel, C.P. Distinct roles for ADAM10 and ADAM17 in ectodomain shedding of six EGFR ligands. J. Cell Biol. 2004, 164, 769-779. [CrossRef] [PubMed]

122. Sternlicht, M.D.; Sunnarborg, S.W.; Kouros-Mehr, H.; Yu, Y.; Lee, D.C.; Werb, Z. Mammary ductal morphogenesis requires paracrine activation of stromal EGFR via ADAM17-dependent shedding of epithelial amphiregulin. Development 2005, 132, 3923-3933. [CrossRef] [PubMed]

123. Dijkstra, A.; Postma, D.S.; Noordhoek, J.A.; Lodewijk, M.E.; Kauffman, H.F.; ten Hacken, N.H.; Timens, W. Expression of ADAMs ("a disintegrin and metalloprotease") in the human lung. Virchows Arch. 2009, 454, 441-449. [CrossRef] [PubMed]

124. Paulissen, G.; Rocks, N.; Gueders, M.M.; Crahay, C.; Quesada-Calvo, F.; Bekaert, S.; Hacha, J.; El Hour, M.; Foidart, J.M.; Noel, A.; et al. Role of ADAM and ADAMTS metalloproteinases in airway diseases. Respir. Res. 2009, 10, 127. [CrossRef]

125. Dreymueller, D.; Martin, C.; Kogel, T.; Pruessmeyer, J.; Hess, F.M.; Horiuchi, K.; Uhlig, S.; Ludwig, A. Lung endothelial ADAM17 regulates the acute inflammatory response to lipopolysaccharide. EMBO Mol. Med. 2012, 4, 412-423. [CrossRef]

126. Horiuchi, K.; Kimura, T.; Miyamoto, T.; Takaishi, H.; Okada, Y.; Toyama, Y.; Blobel, C.P. Cutting edge: TNF-alpha-converting enzyme (TACE/ADAM17) inactivation in mouse myeloid cells prevents lethality from endotoxin shock. J. Immunol. 2007, 179, 2686-2689. [CrossRef]

127. Weskamp, G.; Mendelson, K.; Swendeman, S.; Le Gall, S.; Ma, Y.; Lyman, S.; Hinoki, A.; Eguchi, S.; Guaiquil, V.; Horiuchi, K. Pathological neovascularization is reduced by inactivation of ADAM17 in endothelial cells but not in pericytes. Circ. Res. 2010, 106, 932-940. [CrossRef]

128. Arndt, P.G.; Strahan, B.; Wang, Y.; Long, C.; Horiuchi, K.; Walcheck, B. Leukocyte ADAM17 regulates acute pulmonary inflammation. PLoS ONE 2011, 6, e19938. [CrossRef]

129. Bergmeier, W.; Piffath, C.L.; Cheng, G.; Dole, V.S.; Zhang, Y.; von Andrian, U.H.; Wagner, D.D. Tumor necrosis factor-alpha-converting enzyme (ADAM17) mediates GPIbalpha shedding from platelets in vitro and in vivo. Circ. Res. 2004, 95, 677-683. [CrossRef] 
130. Chalaris, A.; Adam, N.; Sina, C.; Rosenstiel, P.; Lehmann-Koch, J.; Schirmacher, P.; Hartmann, D.; Cichy, J.; Gavrilova, O.; Schreiber, S.; et al. Critical role of the disintegrin metalloprotease ADAM17 for intestinal inflammation and regeneration in mice. J. Exp. Med. 2010, 207, 1617-1624. [CrossRef]

131. Saad, M.I.; McLeod, L.; Yu, L.; Ebi, H.; Ruwanpura, S.; Sagi, I.; Rose-John, S.; Jenkins, B.J. The ADAM17 protease promotes tobacco smoke carcinogen-induced lung tumourigenesis. Carcinogenesis 2019. in-press.

132. Schmidt, S.; Schumacher, N.; Schwarz, J.; Tangermann, S.; Kenner, L.; Schlederer, M.; Sibilia, M.; Linder, M.; Altendorf-Hofmann, A.; Knösel, T.; et al. ADAM17 is required for EGF-R-induced intestinal tumors via IL-6 trans-signaling. J. Exp. Med. 2018, 215, 1205-1225. [CrossRef] [PubMed]

133. Arribas, J.; Coodly, L.; Vollmer, P.; Kishimoto, T.K.; Rose-John, S.; Massague, J. Diverse cell surface protein ectodomains are shed by a system sensitive to metalloprotease inhibitors. J. Biol. Chem. 1996, 271, 11376-11382. [CrossRef] [PubMed]

134. Hall, K.C.; Blobel, C.P. Interleukin-1 stimulates ADAM17 through a mechanism independent of its cytoplasmic domain or phosphorylation at threonine 735. PLoS ONE 2012, 7, e31600. [CrossRef] [PubMed]

135. Armstrong, L.; Godinho, S.I.; Uppington, K.M.; Whittington, H.A.; Millar, A.B. Contribution of TNF-alpha converting enzyme and proteinase-3 to TNF-alpha processing in human alveolar macrophages. Am. J. Respir. Cell Mol. Biol. 2006, 34, 219-225. [CrossRef] [PubMed]

136. Brandl, K.; Sun, L.; Neppl, C.; Siggs, O.M.; Le Gall, S.M.; Tomisato, W.; Li, X.; Du, X.; Maennel, D.N.; Blobel, C.P.; et al. MyD88 signaling in nonhematopoietic cells protects mice against induced colitis by regulating specific EGF receptor ligands. Proc. Natl. Acad. Sci. USA 2010, 107, 19967-19972. [CrossRef]

137. Prenzel, N.; Zwick, E.; Daub, H.; Leserer, M.; Abraham, R.; Wallasch, C.; Ullrich, A. EGF receptor transactivation by G-protein-coupled receptors requires metalloproteinase cleavage of proHB-EGF. Nature 1999, 402, 884-888. [CrossRef]

138. Scheller, J.; Chalaris, A.; Garbers, C.; Rose-John, S. ADAM17: A molecular switch to control inflammation and tissue regeneration. Trends Immunol. 2011, 32, 380-387. [CrossRef]

139. Rose-John, S. ADAM17, shedding, TACE as therapeutic targets. Pharmacol. Res. 2013, 71, 19-22. [CrossRef]

140. Schlondorff, J.; Becherer, J.D.; Blobel, C.P. Intracellular maturation and localization of the tumour necrosis factor alpha convertase (TACE). Biochem. J. 2000, 347, 131-138. [CrossRef]

141. Milla, M.E.; Leesnitzer, M.A.; Moss, M.L.; Clay, W.C.; Carter, H.L.; Miller, A.B.; Su, J.L.; Lambert, M.H.; Willard, D.H.; Sheeley, D.M.; et al. Specific sequence elements are required for the expression of functional tumor necrosis factor-alpha-converting enzyme (TACE). J. Biol. Chem. 1999, 274, 30563-30570. [CrossRef] [PubMed]

142. Gonzales, P.E.; Solomon, A.; Miller, A.B.; Leesnitzer, M.A.; Sagi, I.; Milla, M.E. Inhibition of the tumor necrosis factor- $\alpha$-converting enzyme by its pro domain. J. Biol. Chem. 2004, 279, 31638-31645. [CrossRef] [PubMed]

143. Wong, E.; Cohen, T.; Romi, E.; Levin, M.; Peleg, Y.; Arad, U.; Yaron, A.; Milla, M.E.; Sagi, I. Harnessing the natural inhibitory domain to control TNFalpha Converting Enzyme (TACE) activity in vivo. Sci. Rep. 2016, 6, 35598. [CrossRef] [PubMed]

144. Cavadas, M.; Oikonomidi, I.; Gaspar, C.J.; Burbridge, E.; Badenes, M.; Felix, I.; Bolado, A.; Hu, T.; Bileck, A.; Gerner, C.; et al. Phosphorylation of iRhom 2 Controls Stimulated Proteolytic Shedding by the Metalloprotease ADAM17/TACE. Cell Rep. 2017, 21, 745-757. [CrossRef] [PubMed]

145. Adrain, C.; Zettl, M.; Christova, Y.; Taylor, N.; Freeman, M. Tumor necrosis factor signaling requires iRhom2 to promote trafficking and activation of TACE. Science 2012, 335, 225-228. [CrossRef] [PubMed]

146. Christova, Y.; Adrain, C.; Bambrough, P.; Ibrahim, A.; Freeman, M. Mammalian iRhoms have distinct physiological functions including an essential role in TACE regulation. EMBO Rep. 2013, 14, 884-890. [CrossRef] [PubMed]

147. Dulloo, I.; Muliyil, S.; Freeman, M. The molecular, cellular and pathophysiological roles of iRhom pseudoproteases. Open Biol. 2019, 9, 190003. [CrossRef] [PubMed]

148. Lemberg, M.K.; Freeman, M. Functional and evolutionary implications of enhanced genomic analysis of rhomboid intramembrane proteases. Genome Res. 2007, 17, 1634-1646. [CrossRef] [PubMed]

149. Grieve, A.G.; Xu, H.; Künzel, U.; Bambrough, P.; Sieber, B.; Freeman, M. Phosphorylation of iRhom 2 at the plasma membrane controls mammalian TACE-dependent inflammatory and growth factor signalling. Elife 2017, 6, e23968. [CrossRef] 
150. Groth, E.; Pruessmeyer, J.; Babendreyer, A.; Schumacher, J.; Pasqualon, T.; Dreymueller, D.; Higashiyama, S.; Lorenzen, I.; Grötzinger, J.; Cataldo, D. Stimulated release and functional activity of surface expressed metalloproteinase ADAM17 in exosomes. Biochim. Biophys. Acta Mol. Cell. Res. 2016, 1863, 2795-2808. [CrossRef]

151. Diaz-Rodriguez, E.; Montero, J.C.; Esparís-Ogando, A.; Yuste, L.; Pandiella, A. Extracellular signal-regulated kinase phosphorylates tumor necrosis factor $\alpha$-converting enzyme at threonine 735: A potential role in regulated shedding. Mol. Biol. Cell 2002, 13, 2031-2044. [CrossRef] [PubMed]

152. Fan, H.; Derynck, R. Ectodomain shedding of TGF- $\alpha$ and other transmembrane proteins is induced by receptor tyrosine kinase activation and MAP kinase signaling cascades. EMBO J. 1999, 18, 6962-6972. [CrossRef] [PubMed]

153. Xu, P.; Derynck, R. Direct activation of TACE-mediated ectodomain shedding by p38 MAP kinase regulates EGF receptor-dependent cell proliferation. Mol. Cell 2010, 37, 551-566. [CrossRef] [PubMed]

154. Xu, P.; Liu, J.; Sakaki-Yumoto, M.; Derynck, R. TACE activation by MAPK-mediated regulation of cell surface dimerization and TIMP3 association. Sci. Signal. 2012, 5, ra34. [CrossRef] [PubMed]

155. Brill, A.; Chauhan, A.K.; Canault, M.; Walsh, M.T.; Bergmeier, W.; Wagner, D.D. Oxidative stress activates ADAM17/TACE and induces its target receptor shedding in platelets in a p38-dependent fashion. Cardiovasc. Res. 2009, 84, 137-144. [CrossRef] [PubMed]

156. Soond, S.M.; Everson, B.; Riches, D.W.; Murphy, G. ERK-mediated phosphorylation of Thr735 in $\mathrm{TNF} \alpha$-converting enzyme and its potential role in TACE protein trafficking. J. Cell Sci. 2005, 118, 2371-2380. [CrossRef] [PubMed]

157. Effenberger, T.; von der Heyde, J.; Bartsch, K.; Garbers, C.; Schulze-Osthoff, K.; Chalaris, A.; Murphy, G.; Rose-John, S.; Rabe, B. Senescence-associated release of transmembrane proteins involves proteolytic processing by ADAM17 and microvesicle shedding. FASEB J. 2014, 28, 4847-4856. [CrossRef] [PubMed]

158. Amour, A.; Slocombe, P.M.; Webster, A.; Butler, M.; Knight, C.G.; Smith, B.J.; Stephens, P.E.; Shelley, C.; Hutton, M.; Knäuper, V. TNF- $\alpha$ converting enzyme (TACE) is inhibited by TIMP-3. FEBS Lett. 1998, 435, 39-44. [CrossRef]

159. Wisniewska, M.; Goettig, P.; Maskos, K.; Belouski, E.; Winters, D.; Hecht, R.; Black, R.; Bode, W. Structural determinants of the ADAM inhibition by TIMP-3: Crystal structure of the TACE-N-TIMP-3 complex. J. Mol. Biol. 2008, 381, 1307-1319. [CrossRef]

160. Mohammed, F.F.; Smookler, D.S.; Taylor, S.E.; Fingleton, B.; Kassiri, Z.; Sanchez, O.H.; English, J.L.; Matrisian, L.M.; Au, B.; Yeh, W.-C. Abnormal TNF activity in Timp3-/- mice leads to chronic hepatic inflammation and failure of liver regeneration. Nat. Genet. 2004, 36, 969-977. [CrossRef]

161. Chapnick, D.A.; Bunker, E.; Liu, X. A biosensor for the activity of the "sheddase" TACE (ADAM17) reveals novel and cell type-specific mechanisms of TACE activation. Sci. Signal. 2015, 8, rs1. [CrossRef] [PubMed]

162. Cho, Y.; Park, D.; Kim, C. Disruption of TACE-filamin interaction can inhibit TACE-mediated ectodomain shedding. Biochem. Biophys. Res. Commun. 2017, 490, 997-1003. [CrossRef] [PubMed]

163. Gutiérrez-López, M.D.; Gilsanz, A.; Yáñez-Mó, M.; Ovalle, S.; Lafuente, E.M.; Domínguez, C.; Monk, P.N.; González-Alvaro, I.; Sánchez-Madrid, F.; Cabañas, C. The sheddase activity of ADAM17/TACE is regulated by the tetraspanin CD9. Cell. Mol. Life Sci. 2011, 68, 3275-3292. [CrossRef] [PubMed]

164. Wang, Y.; Herrera, A.H.; Li, Y.; Belani, K.K.; Walcheck, B. Regulation of mature ADAM17 by redox agents for L-selectin shedding. J. Immunol. 2009, 182, 2449-2457. [CrossRef] [PubMed]

165. Lemjabbar-Alaoui, H.; Sidhu, S.S.; Mengistab, A.; Gallup, M.; Basbaum, C. TACE/ADAM-17 phosphorylation by PKC-epsilon mediates premalignant changes in tobacco smoke-exposed lung cells. PLoS ONE 2011, 6, e17489. [CrossRef]

166. Tellier, E.; Canault, M.; Rebsomen, L.; Bonardo, B.; Juhan-Vague, I.; Nalbone, G.; Peiretti, F. The shedding activity of ADAM17 is sequestered in lipid rafts. Exp. Cell Res. 2006, 312, 3969-3980. [CrossRef] [PubMed]

167. Dang, M.; Armbruster, N.; Miller, M.A.; Cermeno, E.; Hartmann, M.; Bell, G.W.; Root, D.E.; Lauffenburger, D.A.; Lodish, H.F.; Herrlich, A. Regulated ADAM17-dependent EGF family ligand release by substrate-selecting signaling pathways. Proc. Natl. Acad. Sci. USA 2013, 110, 9776-9781. [CrossRef]

168. Düsterhöft, S.; Höbel, K.; Oldefest, M.; Lokau, J.; Waetzig, G.H.; Chalaris, A.; Garbers, C.; Scheller, J.; Rose-John, S.; Lorenzen, I. A disintegrin and metalloprotease 17 dynamic interaction sequence, the sweet tooth for the human interleukin 6 receptor. J. Biol. Chem. 2014, 289, 16336-16348. [CrossRef] 
169. Blanchot-Jossic, F.; Jarry, A.; Masson, D.; Bach-Ngohou, K.; Paineau, J.; Denis, M.G.; Laboisse, C.L.; Mosnier, J.F. Up-regulated expression of ADAM17 in human colon carcinoma: Co-expression with EGFR in neoplastic and endothelial cells. J. Pathol. 2005, 207, 156-163. [CrossRef]

170. Kornfeld, J.; Meder, S.; Wohlberg, M.; Friedrich, R.; Rau, T.; Riethdorf, L.; Löning, T.; Pantel, K.; Riethdorf, S. Overexpression of TACE and TIMP3 mRNA in head and neck cancer: Association with tumour development and progression. Br. J. Cancer 2011, 104, 138-145. [CrossRef]

171. Cai, M.; Wang, Z.; Zhang, J.; Zhou, H.; Jin, L.; Bai, R.; Weng, Y. Adam17, a target of Mir-326, promotes Emt-induced cells invasion in lung adenocarcinoma. Cell. Physiol. Biochem. 2015, 36, 1175-1185. [CrossRef] [PubMed]

172. Ni, S.-S.; Zhang, J.; Zhao, W.-L.; Dong, X.-C.; Wang, J.-L. ADAM17 is overexpressed in non-small cell lung cancer and its expression correlates with poor patient survival. Tumor Biol. 2013, 34, 1813-1818. [CrossRef] [PubMed]

173. McGowan, P.M.; Ryan, B.M.; Hill, A.D.; McDermott, E.; O’Higgins, N.; Duffy, M.J. ADAM-17 expression in breast cancer correlates with variables of tumor progression. Clin. Cancer Res. 2007, 13, 2335-2343. [CrossRef] [PubMed]

174. Caiazza, F.; McGowan, P.M.; Mullooly, M.; Murray, A.; Synnott, N.; O’Donovan, N.; Flanagan, L.; Tape, C.J.; Murphy, G.; Crown, J. Targeting ADAM-17 with an inhibitory monoclonal antibody has antitumour effects in triple-negative breast cancer cells. Br. J. Cancer 2015, 112, 1895. [CrossRef]

175. Capone, C.; Dabertrand, F.; Baron-Menguy, C.; Chalaris, A.; Ghezali, L.; Domenga-Denier, V.; Schmidt, S.; Huneau, C.; Rose-John, S.; Nelson, M.T. Mechanistic insights into a TIMP3-sensitive pathway constitutively engaged in the regulation of cerebral hemodynamics. Elife 2016, 5, e17536. [CrossRef]

176. Fang, W.; Qian, J.; Wu, Q.; Chen, Y.; Yu, G. ADAM-17 expression is enhanced by FoxM1 and is a poor prognostic sign in gastric carcinoma. J. Surg. Res. 2017, 220, 223-233. [CrossRef]

177. Kenny, P.A.; Bissell, M.J. Targeting TACE-dependent EGFR ligand shedding in breast cancer. J. Clin. Invest. 2007, 117, 337-345. [CrossRef]

178. Zheng, X.; Jiang, F.; Katakowski, M.; Zhang, Z.G.; Lu, Q.-e.; Chopp, M. ADAM17 promotes breast cancer cell malignant phenotype through EGFR-PI3K-AKT activation. Cancer Biol. Ther. 2009, 8, 1045-1054. [CrossRef]

179. Lin, P.; Sun, X.; Feng, T.; Zou, H.; Jiang, Y.; Liu, Z.; Zhao, D.; Yu, X. ADAM17 regulates prostate cancer cell proliferation through mediating cell cycle progression by EGFR/PI3K/AKT pathway. Mol. Cell. Biochem. 2012, 359, 235-243. [CrossRef]

180. Ye, J.; Yuen, S.M.; Murphy, G.; Xie, R.; Kwok, H.F. Anti-tumor effects of a 'human \& mouse cross-reactive'anti-ADAM17 antibody in a pancreatic cancer model in vivo. Eur. J. Pharm. Sci. 2017, 110, 62-69.

181. Richards, F.M.; Tape, C.J.; Jodrell, D.I.; Murphy, G. Anti-tumour effects of a specific anti-ADAM17 antibody in an ovarian cancer model in vivo. PLoS ONE 2012, 7, e40597. [CrossRef] [PubMed]

182. Zhou, B.-B.S.; Peyton, M.; He, B.; Liu, C.; Girard, L.; Caudler, E.; Lo, Y.; Baribaud, F.; Mikami, I.; Reguart, N. Targeting ADAM-mediated ligand cleavage to inhibit HER3 and EGFR pathways in non-small cell lung cancer. Cancer Cell 2006, 10, 39-50. [CrossRef] [PubMed]

183. Witters, L.; Scherle, P.; Friedman, S.; Fridman, J.; Caulder, E.; Newton, R.; Lipton, A. Synergistic inhibition with a dual epidermal growth factor receptor/HER-2/neu tyrosine kinase inhibitor and a disintegrin and metalloprotease inhibitor. Cancer Res. 2008, 68, 7083-7089. [CrossRef] [PubMed]

184. Newton, R.; Bradley, E.; Levy, R.; Doval, D.; Bondarde, S.; Sahoo, T.; Lokanatha, D.; Julka, P.; Nagarkar, R.; Friedman, S. Clinical benefit of INCB7839, a potent and selective ADAM inhibitor, in combination with trastuzumab in patients with metastatic HER2+ breast cancer. J. Clin. Oncol. 2010, 28, 3025. [CrossRef]

185. Hirata, S.; Murata, T.; Suzuki, D.; Nakamura, S.; Jono-Ohnishi, R.; Hirose, H.; Sawaguchi, A.; Nishimura, S.; Sugimoto, N.; Eto, K. Selective Inhibition of ADAM17 Efficiently Mediates Glycoprotein Ib $\alpha$ Retention During Ex Vivo Generation of Human Induced Pluripotent Stem Cell-Derived Platelets. Stem Cells Transl. Med. 2017, 6, 720-730. [CrossRef] [PubMed]

186. Huang, Y.; Benaich, N.; Tape, C.; Kwok, H.F.; Murphy, G. Targeting the sheddase activity of ADAM17 by an anti-ADAM17 antibody D1 (A12) inhibits head and neck squamous cell carcinoma cell proliferation and motility via blockage of bradykinin induced HERs transactivation. Int. J. Biol. Sci. 2014, 10, 702. [CrossRef] [PubMed] 
187. Baumgart, A.; Seidl, S.; Vlachou, P.; Michel, L.; Mitova, N.; Schatz, N.; Specht, K.; Koch, I.; Schuster, T.; Grundler, R. ADAM17 regulates epidermal growth factor receptor expression through the activation of Notch1 in non-small cell lung cancer. Cancer Res. 2010, 70, 5368-5378. [CrossRef] [PubMed]

188. Sharma, A.; Bender, S.; Zimmermann, M.; Riesterer, O.; Broggini-Tenzer, A.; Pruschy, M.N. Secretome Signature Identifies ADAM17 as Novel Target for Radiosensitization of Non-Small Cell Lung Cancer. Clin. Cancer Res. 2016, 22, 4428-4439. [CrossRef]

189. Friedman, S.; Levy, R.; Garrett, W.; Doval, D.; Bondarde, S.; Sahoo, T.; Lokanatha, D.; Julka, P.; Shenoy, K.; Nagarkar, R. Clinical Benefit of INCB7839, a Potent and Selective Inhibitor of ADAM10 and ADAM17, in Combination with Trastuzumab in Metastatic HER2 Positive Breast Cancer Patients. Cancer Res. 2009, 69 (Suppl. 24). [CrossRef]

190. Infante, J.; Burris, H.; Lewis, N.; Donehower, R.; Redman, J.; Friedman, S.; Scherle, P.; Fridman, J.; Li, J.; Emm, T. A multicenter phase Ib study of the safety, pharmacokinetics, biological activity and clinical efficacy of INCB7839, a potent and selective inhibitor of ADAM10 and ADAM17. Breast Cancer Res. Treat. 2007, 106 (Suppl. 1), 1. [CrossRef]

191. Pecot, C.V.; Calin, G.A.; Coleman, R.L.; Lopez-Berestein, G.; Sood, A.K. RNA interference in the clinic: Challenges and future directions. Nat. Rev. Cancer 2011, 11, 59. [CrossRef] [PubMed]

192. Lv, X.; Li, Y.; Qian, M.; Ma, C.; Jing, H.; Wen, Z.; Qian, D. ADAM17 silencing suppresses the migration and invasion of non-small cell lung cancer. Mol. Med. Report. 2014, 9, 1935-1940. [CrossRef] [PubMed]

193. Yoda, M.; Kimura, T.; Tohmonda, T.; Morioka, H.; Matsumoto, M.; Okada, Y.; Toyama, Y.; Horiuchi, K. Systemic overexpression of $\mathrm{TNF} \alpha$-converting enzyme does not lead to enhanced shedding activity in vivo. PLoS ONE 2013, 8, e54412. [CrossRef] [PubMed]

194. Tan, C.-S.; Gilligan, D.; Pacey, S. Treatment approaches for EGFR-inhibitor-resistant patients with non-small-cell lung cancer. Lancet Oncol. 2015, 16, e447-e459. [CrossRef]

195. Borrell-Pagès, M.; Rojo, F.; Albanell, J.; Baselga, J.; Arribas, J. TACE is required for the activation of the EGFR by TGF- $\alpha$ in tumors. EMBO J. 2003, 22, 1114-1124. [CrossRef] [PubMed]

196. Rizzo, P.; Osipo, C.; Foreman, K.; Golde, T.; Osborne, B.; Miele, L. Rational targeting of Notch signaling in cancer. Oncogene 2008, 27, 5124-5131. [CrossRef] [PubMed]

197. Miller, A.; McLeod, L.; Alhayyani, S.; Szczepny, A.; Watkins, D.; Chen, W.; Enriori, P.; Ferlin, W.; Ruwanpura, S.; Jenkins, B. Blockade of the IL-6 trans-signalling/STAT3 axis suppresses cachexia in Kras-induced lung adenocarcinoma. Oncogene 2017, 36, 3059. [CrossRef] [PubMed]

198. Sigismund, S.; Avanzato, D.; Lanzetti, L. Emerging functions of the EGFR in cancer. Mol. Oncol. 2018, 12, 3-20. [CrossRef]

199. Tomoshige, K.; Guo, M.; Tsuchiya, T.; Fukazawa, T.; Fink-Baldauf, I.M.; Stuart, W.D.; Naomoto, Y.; Nagayasu, T.; Maeda, Y. An EGFR ligand promotes EGFR-mutant but not KRAS-mutant lung cancer in vivo. Oncogene 2018, 1, 3894. [CrossRef]

200. Gazdar, A.F. Activating and resistance mutations of EGFR in non-small-cell lung cancer: Role in clinical response to EGFR tyrosine kinase inhibitors. Oncogene 2009, 28 (Suppl. 1), S24-S31. [CrossRef]

201. Brachmann, R.; Lindquist, P.B.; Nagashima, M.; Kohr, W.; Lipari, T.; Napier, M.; Derynck, R. Transmembrane TGF-alpha precursors activate EGF/TGF-alpha receptors. Cell 1989, 56, 691-700. [CrossRef]

202. Higashiyama, S.; Iwamoto, R.; Goishi, K.; Raab, G.; Taniguchi, N.; Klagsbrun, M.; Mekada, E. The membrane protein CD9/DRAP 27 potentiates the juxtacrine growth factor activity of the membrane-anchored heparin-binding EGF-like growth factor. J. Cell Biol. 1995, 128, 929-938. [CrossRef] [PubMed]

203. Wong, S.T.; Winchell, L.F.; McCune, B.K.; Earp, H.S.; Teixido, J.; Massague, J.; Herman, B.; Lee, D.C. The TGF-alpha precursor expressed on the cell surface binds to the EGF receptor on adjacent cells, leading to signal transduction. Cell 1989, 56, 495-506. [CrossRef]

204. Yang, H.; Jiang, D.; Li, W.; Liang, J.; Gentry, L.E.; Brattain, M.G. Defective cleavage of membrane bound TGF [alpha] leads to enhanced activation of the EGF receptor in malignant cells. Oncogene 2000, 19, 1901. [CrossRef] [PubMed]

205. Hurbin, A.; Dubrez, L.; Coll, J.-L.; Favrot, M.-C. Inhibition of apoptosis by amphiregulin via an insulin-like growth factor-1 receptor-dependent pathway in non-small cell lung cancer cell lines. J. Biol. Chem. 2002, 277, 49127-49133. [CrossRef] [PubMed] 
206. Ishikawa, N.; Daigo, Y.; Takano, A.; Taniwaki, M.; Kato, T.; Hayama, S.; Murakami, H.; Takeshima, Y.; Inai, K.; Nishimura, H. Increases of amphiregulin and transforming growth factor- $\alpha$ in serum as predictors of poor response to gefitinib among patients with advanced non-small cell lung cancers. Cancer Res. 2005, 65, 9176-9184. [CrossRef] [PubMed]

207. Logeat, F.; Bessia, C.; Brou, C.; LeBail, O.; Jarriault, S.; Seidah, N.G.; Israël, A. The Notch1 receptor is cleaved constitutively by a furin-like convertase. Proc. Natl. Acad. Sci. USA 1998, 95, 8108-8112. [CrossRef] [PubMed]

208. Gordon, W.R.; Arnett, K.L.; Blacklow, S.C. The molecular logic of Notch signaling-a structural and biochemical perspective. J. Cell Sci. 2008, 121, 3109-3119. [CrossRef] [PubMed]

209. Bray, S.J. Notch signalling: A simple pathway becomes complex. Nat. Rev. Mol. Cell Biol. 2006, 7, 678-689. [CrossRef] [PubMed]

210. Bozkulak, E.C.; Weinmaster, G. Selective use of ADAM10 and ADAM17 in activation of Notch1 signaling. Mol. Cell. Biol. 2009, 29, 5679-5695. [CrossRef] [PubMed]

211. Eliasz, S.; Liang, S.; Chen, Y.; De Marco, M.A.; Machek, O.; Skucha, S.; Miele, L.; Bocchetta, M. Notch-1 stimulates survival of lung adenocarcinoma cells during hypoxia by activating the IGF-1R pathway. Oncogene 2010, 29, 2488. [CrossRef] [PubMed]

212. Baumgart, A.; Mazur, P.; Anton, M.; Rudelius, M.; Schwamborn, K.; Feuchtinger, A.; Behnke, K.; Walch, A.; Braren, R.; Peschel, C. Opposing role of Notch1 and Notch2 in a Kras G12D-driven murine non-small cell lung cancer model. Oncogene 2015, 34, 578. [CrossRef] [PubMed]

213. Jones, S.A.; Jenkins, B.J. Recent insights into targeting the IL-6 cytokine family in inflammatory diseases and cancer. Nat. Rev. Immunol. 2018, 1, 773-789. [CrossRef] [PubMed]

214. Scheller, J.; Garbers, C.; Rose-John, S. Interleukin-6: From basic biology to selective blockade of pro-inflammatory activities. Semin. Immunol. 2014, 26, 2-12. [CrossRef] [PubMed]

215. Ullah, M.A.; Revez, J.A.; Loh, Z.; Simpson, J.; Zhang, V.; Bain, L.; Varelias, A.; Rose-John, S.; Blumenthal, A.; Smyth, M.J.; et al. Allergen-induced IL-6 trans-signaling activates gammadelta T cells to promote type 2 and type 17 airway inflammation. J. Allergy Clin. Immunol. 2015, 136, 1065-1073. [CrossRef] [PubMed]

216. Ruwanpura, S.M.; McLeod, L.; Dousha, L.F.; Seow, H.J.; Alhayyani, S.; Tate, M.D.; Deswaerte, V.; Brooks, G.D.; Bozinovski, S.; MacDonald, M.; et al. Therapeutic Targeting of the IL-6 Trans-Signaling/Mechanistic Target of Rapamycin Complex 1 Axis in Pulmonary Emphysema. Am. J. Respir. Crit. Care Med. 2016, 194, 1494-1505. [CrossRef] [PubMed]

217. Rose-John, S. The Soluble Interleukin 6 Receptor: Advanced Therapeutic Options in Inflammation. Clin. Pharmacol. Ther. 2017, 102, 591-598. [CrossRef] [PubMed]

218. Lacroix, M.; Rousseau, F.; Guilhot, F.; Malinge, P.; Magistrelli, G.; Herren, S.; Jones, S.A.; Jones, G.W.; Scheller, J.; Lissilaa, R. Novel insights into interleukin 6 (IL-6) cis-and trans-signaling pathways by differentially manipulating the assembly of the IL-6 signaling complex. J. Biol. Chem. 2015, 290, 26943-26953. [CrossRef]

219. Schumacher, N.; Meyer, D.; Mauermann, A.; von der Heyde, J.; Wolf, J.; Schwarz, J.; Knittler, K.; Murphy, G.; Michalek, M.; Garbers, C. Shedding of endogenous interleukin-6 receptor (IL-6R) is governed by a disintegrin and metalloproteinase (ADAM) proteases while a full-length IL-6R isoform localizes to circulating microvesicles. J. Biol. Chem. 2015, 290, 26059-26071. [CrossRef]

220. Rose-John, S.; Winthrop, K.; Calabrese, L. The role of IL-6 in host defence against infections: Immunobiology and clinical implications. Nat. Rev. Rheumatol. 2017, 13, 399. [CrossRef]

(C) 2019 by the authors. Licensee MDPI, Basel, Switzerland. This article is an open access article distributed under the terms and conditions of the Creative Commons Attribution (CC BY) license (http://creativecommons.org/licenses/by/4.0/). 